\title{
Hybrid Chelator-Based PSMA Radiopharmaceuticals: Translational Approach
}

\author{
Hanane Lahnif ${ }^{1,+}\left(\mathbb{D}\right.$, Tilmann Grus ${ }^{1,+} \oplus$, Stefanie Pektor ${ }^{2}$, Lukas Greifenstein ${ }^{1,3}$, Mathias Schreckenberger ${ }^{2}$ \\ and Frank Rösch ${ }^{1, *}$
}

1 Department of Chemistry-TRIGA Site, Johannes Gutenberg University Mainz, 55128 Mainz, Germany; halahnif@uni-mainz.de (H.L.); t.grus@uni-mainz.de (T.G.); greifenstein@curanosticum.de (L.G.)

2 Department of Nuclear Medicine, University Medical Center Mainz, 55131 Mainz, Germany; Stefanie.Pektor@unimedizin-mainz.de (S.P.); mathias.schreckenberger@unimedizin-mainz.de (M.S.)

3 Curanosticum Wiesbaden-Frankfurt, 65191 Wiesbaden, Germany

* Correspondence: frank.roesch@uni-mainz.de; Tel.: +49-6131-39-25302

+ These authors contributed equally to this work.

Citation: Lahnif, H.; Grus, T.; Pektor, S.; Greifenstein, L.; Schreckenberger, M.; Rösch, F. Hybrid Chelator-Based PSMA Radiopharmaceuticals: Translational Approach. Molecules 2021, 26, 6332. https://doi.org// 10.3390molecules 26216332

Academic Editors: Aline Nonat and Ali Ouadi

Received: 27 September 2021

Accepted: 18 October 2021

Published: 20 October 2021

Publisher's Note: MDPI stays neutral with regard to jurisdictional claims in published maps and institutional affiliations.

\section{Copyright: (C) 2021 by the authors.} Licensee MDPI, Basel, Switzerland. This article is an open access article distributed under the terms and conditions of the Creative Commons Attribution (CC BY) license (https:// creativecommons.org/licenses/by/ $4.0 /)$.

\begin{abstract}
Background: Prostate-specific membrane antigen (PSMA) has been extensively studied in the last decade. It became a promising biological target in the diagnosis and therapy of PSMAexpressing cancer diseases. Although there are several radiolabeled PSMA inhibitors available, the search for new compounds with improved pharmacokinetic properties and simplified synthesis is still ongoing. In this study, we developed PSMA ligands with two different hybrid chelators and a modified linker. Both compounds have displayed a promising pharmacokinetic profile. (2) Methods: DATA ${ }^{5 \mathrm{~m}}$.SA.KuE and AAZTA ${ }^{5}$.SA.KuE were synthesized. DATA ${ }^{5 \mathrm{~m}}$.SA.KuE was labeled with gallium-68 and radiochemical yields of various amounts of precursor at different temperatures were determined. Complex stability in phosphate-buffered saline (PBS) and human serum (HS) was examined at $37^{\circ} \mathrm{C}$. Binding affinity and internalization ratio were determined in in vitro assays using PSMA-positive LNCaP cells. Tumor accumulation and biodistribution were evaluated in vivo and ex vivo using an LNCaP Balb/c nude mouse model. All experiments were conducted with PSMA-11 as reference. (3) Results: DATA ${ }^{5 m}$.SA.KuE was synthesized successfully. AAZTA ${ }^{5}$.SA.KuE was synthesized and labeled according to the literature. Radiolabeling of DATA ${ }^{5 \mathrm{~m}}$.SA.KuE with gallium-68 was performed in ammonium acetate buffer $(1 \mathrm{M}, \mathrm{pH}$ 5.5). High radiochemical yields (>98\%) were obtained with $5 \mathrm{nmol}$ at $70{ }^{\circ} \mathrm{C}, 15 \mathrm{nmol}$ at $50{ }^{\circ} \mathrm{C}$, and $60 \mathrm{nmol}(50 \mu \mathrm{g})$ at room temperature. $\left[{ }^{68} \mathrm{Ga}\right] \mathrm{Ga}$ DATA $^{5 \mathrm{~m}}$.SA.KuE was stable in human serum as well as in PBS after $120 \mathrm{~min}$. PSMA binding affinities of AAZTA ${ }^{5}$.SA.KuE and DATA ${ }^{5 \mathrm{~m}}$.SA.KuE were in the nanomolar range. PSMA-specific internalization ratio was comparable to PSMA-11. In vivo and ex vivo studies of $\left[{ }^{177} \mathrm{Lu}\right] \mathrm{Lu}-\mathrm{AAZTA}{ }^{5}$.SA.KuE, $\left[{ }^{44} \mathrm{Sc}\right] \mathrm{Sc}-\mathrm{AAZTA}{ }^{5}$.SA.KuE and $\left[{ }^{68} \mathrm{Ga}\right] \mathrm{Ga}-\mathrm{DATA}{ }^{5 \mathrm{~m}}$.SA.KuE displayed specific accumulation in the tumor along with fast clearance and reduced off-target uptake. (4) Conclusions: Both KuE-conjugates showed promising properties especially in vivo allowing for translational theranostic use.
\end{abstract}

Keywords: prostate specific membrane antigen PSMA; hybrid chelator; radionuclide diagnosis and therapy

\section{Introduction}

Prostate-specific membrane antigen (PSMA) has become a very popular target in the diagnosis and treatment of prostate cancer in the last decade. PSMA is a glycoprotein with several functions originating from its glutamate-carboxypeptidase activity. In the central nervous system, PSMA acts as NAALADase, which cleaves the glutamate moiety from the neurotransmitter N-acetyl aspartyl glutamate. However, in the proximal small intestine, this enzyme, called folate hydrolase FOLH1, releases glutamate residues from poly-glutamated folate [1,2]. Besides these physiological functions, PSMA seems to play an important role in prostate carcinogenesis since it is highly expressed in prostate tumor cells. 
This expression correlates with the aggressiveness and invasiveness of the tumor [3-5], and is a major reason for choosing PSMA as a molecular target in the management of prostate cancer (PC).

Prostate cancer is the second most common cancer among men and the fifth leading cause of death worldwide [6,7]. However, early detection of PC in a localized stage can significantly reduce its mortality, leading to a 5-year survival rate of more than $90 \%$ [8]. In contrast, late-stage tumors are aggressive and almost resistant to available therapies. Metastatic castration-resistant prostate cancer (mCRPC) is one of the most aggressive forms of prostate cancer, with poor outcomes and restricted therapy options [9]. One of the most promising approaches herein is PSMA-targeted radioligand diagnosis and therapy. The unique characteristics of PSMA as a molecular target in combination with the small-molecule PSMA inhibitors as target vectors paved the way for the development of highly sensitive radiopharmaceuticals like the PET radioligand $\left[{ }^{68} \mathrm{Ga}\right] \mathrm{Ga}-\mathrm{PSMA}-11$ and its therapeutic counterpart [ $\left.{ }^{177} \mathrm{Lu}\right] \mathrm{Lu}-\mathrm{PSMA}-617[10,11]$.

One of the challenges in designing appropriate PSMA inhibitors for theranostic use is balancing the reduction of off-target accumulation in order to minimize the exposure and irradiation of excretory organs and other tissues where physiological PSMA expression is known, such as the salivary glands and the kidneys [12-15], with the development of PSMA ligands which can be easily synthesized and effectively labeled. To address some of these concerns, we developed AAZTA ${ }^{5}$.SA.KuE and DATA ${ }^{5 \mathrm{~m}}$.SA.KuE.

Like all PSMA ligands, the herein described PSMA radiopharmaceuticals consist of three parts: chelator, linker moiety, and a KuE-based PSMA-targeting vector.

The chelator is responsible for the introduction of the radionuclide. In this study, the bifunctional hybrid chelators DATA ${ }^{5 \mathrm{~m}}$ (6-pentanoic acid-6-aminoperhydro-1,4-diazapinetriacetate) and AAZTA ${ }^{5}$ (6-pentanoic acid-6-aminoperhydro-1,4-diazepine tetra-acetic acid) are used (Figure 1). With regard to radiometals, hybrid chelators combine the positive complexation properties of acyclic chelators, such as fast complexation kinetics at mild temperatures, with the advantages of cyclic chelators, such as prolonged complex stability [16,17]. In these structures, the two tertiary diazepine amines provide the cyclic component for complexation. Another amine outside the perhydro-1,4-diazepine backbone provides another complexation unit (acyclic component). The remaining complexation sites are provided by carboxy groups alkylated to the amines [16,18-20].<smiles>O=C(O)CCCCC1(N(CC(=O)O)CC(=O)O)CN2CCN(CC(=O)O)C1C2</smiles>

AAZTA $^{5}$<smiles>CN(CC(=O)O)C1(CCCCC(=O)O)CN2CCN(CC(=O)O)CC1(CC(=O)O)C2</smiles>

DATA $^{5 m}$

Figure 1. Bifunctional derivatives of the hybrid chelators AAZTA ${ }^{5}$ and DATA ${ }^{5 m}$.

AAZTA $^{5}$ shows ideal labeling properties for transition metals, such as scandium as well as for lanthanides, e.g., gadolinium and lutetium. Thus, AAZTA ${ }^{5}$ is suitable as a chelator for diagnostic use (e.g., scandium-44), as well as for therapeutic applications (e.g., lutetium-177) $[17,21,22]$.

The DATA ${ }^{5 \mathrm{~m}}$ chelator has optimal labeling properties at mild conditions for the generator-based PET nuclide gallium-68. Furthermore, the AAZTA and DATA chelators are also suitable for instant kit-labeling applications with e.g., lutetium-177 and gallium-68 [17,23]. 
Lysine-urea-glutamate (KuE) has been established as a PSMA inhibitor. KuE consists of lysine and glutamate which are both linked to each other via a urea unit. KuE is based on the natural PSMA-substrate NAAG, but cannot be cleaved by the enzyme [10]. Both PSMA-617 and PSMA-11 carry this structural unit as the PSMA-binding entity [24].

The third structural element found in PSMA radiopharmaceuticals is the linker moiety, connecting the chelator to the urea-based target vector. In addition to the function of coupling, these linkers are usually designed to improve the pharmacokinetics of the compounds [10]. These moieties can interact with the aromatic-binding region of the PSMA binding pocket, leading to an increase in the affinity of the PSMA ligand [25]. The coupling of $\mathrm{KuE}$ is achieved via the side-chain amine of the lysine. Usually, amide coupling reactions are used for this purpose. Alternatively, conjugation can be achieved by using square acid diethyl esters (SADE). This group allows two amines to be selectively coupled via asymmetric amidation, forming a squaramide. This simplifies the synthesis in so far as, for example, no protective group chemistry is required, as is the case with standard amide couplings. The coupling reaction is selective with amines only and by controlling the amidation of both squaric acid esters via $\mathrm{pH}$ [17,26-29]. The control of the asymmetric amidation via the $\mathrm{pH}$ value can be explained by the different aromaticity and thus the different mesomeric stabilities of the individual intermediates at the different $\mathrm{pH}$ values (Figure 2) [30-32].

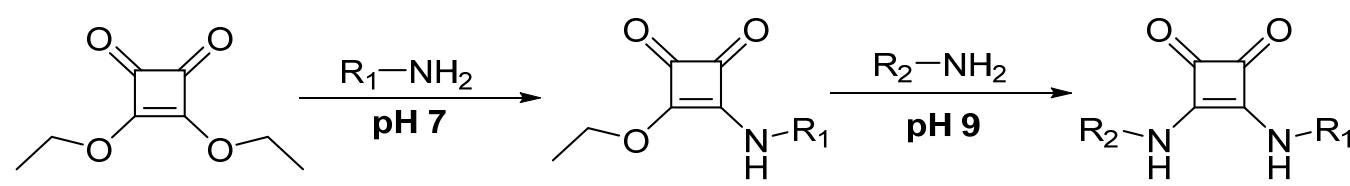

Figure 2. Asymmetric amidation of SADE with different amines. The reactions are driven by change in aromaticity of the different intermediates.

With regard to PSMA radiopharmaceuticals, the use of squaric acid shows another advantage. Squaric acid has an aromatic character and can therefore interact with the aromatic binding region in the PSMA binding pocket resulting in an increased affinity. Greifenstein et al. recently demonstrated that a square amide containing DOTAGA-KuE derivative is comparable to the standard compounds PSMA-617 and PSMA-11 in terms of in vitro binding affinity, tumor accumulation, and in vivo kinetics [28].

\section{Results}

\subsection{Organic Synthesis}

\subsubsection{Synthesis of AAZTA ${ }^{5}$.SA.KuE Was according to Literature}

The synthesis of the DATA chelator is based on the synthesis described by Farkas et al. [16] and Greifenstein et al. [17]. It was synthesized according to Figure 3.

$N, N^{\prime}$-dibenzylethyldiamines were first reacted with tert-butyl bromoacetate to give the di-alkylated compound $\mathbf{1}$. The benzyl protecting groups were then removed by reduction. The diazepane 3 was formed by a double Mannich reaction. For this purpose, 2-nitrocyclohexanone was used, the ring of which was opened using the anion exchanger Amberlyst ${ }^{\circledR}$ A21. In the following Mannich reaction, this ring-opened intermediate reacted with 2 to form the desired diazepane 3.

After reduction of the nitro group (4), tert-butyl bromoacetate was added in an undercurrent to give the mono-alkylated compound 5 . The secondary amine of 5 was then methylated in a reductive amination. This led to the protected chelator DATA ${ }^{5 \mathrm{~m}} \mathbf{6}$. In order to functionalize 6 with the target vector, however, it was necessary to introduce an ethylenediamine bridge. For this purpose, the methyl ester of 6 was saponified using lithium hydroxide (compound 7) and the mono Boc-protected ethylenediamine was linked via an amide coupling to get $\mathbf{8}$. After an acidic deprotection compound $\mathbf{9}$ could be conjugated to the target vector using squaric acid. 


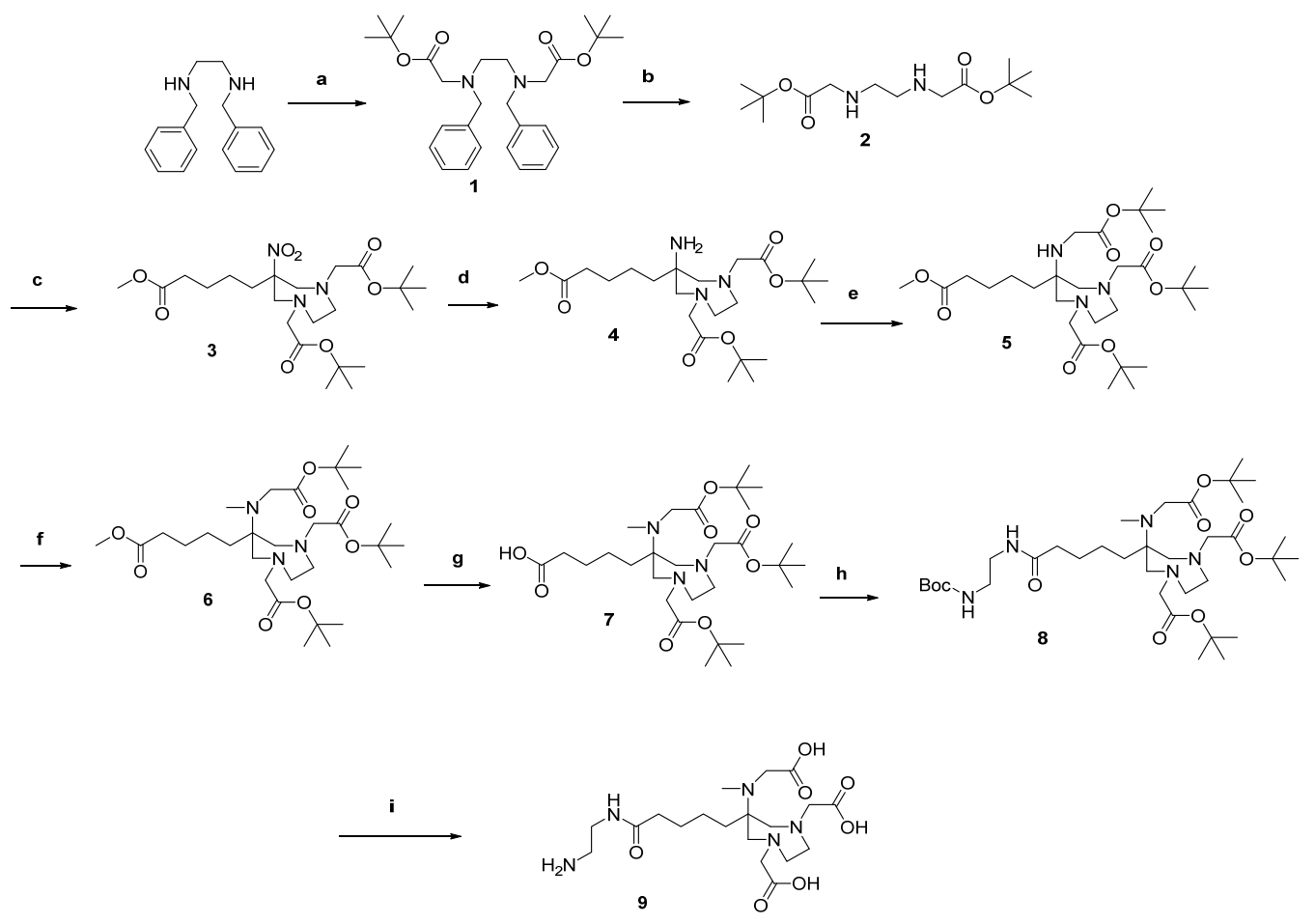

Figure 3. Synthesis of DATA ${ }^{5 \mathrm{~m}}$ : (a) tert-butyl bromoacetate, $\mathrm{Na}_{2} \mathrm{CO}_{3}, \mathrm{MeCN}, 96 \%$; (b) $\mathrm{Pd} / \mathrm{C}, \mathrm{EtOH}$, formic acid, $\mathrm{H}_{2}, 98 \%$; (c) paraformaldehyde, 2-nitrocyclohexanone, $\mathrm{MeOH}, 77 \%$; (d) Raney ${ }^{\circledR}$-Nickel, EtOH, $\mathrm{H}_{2}, 72 \%$; (e) tert-butyl bromoacetate, DIPEA, MeCN, 62\%; (f) Formalin (37\%), $\mathrm{AcOH}, \mathrm{NaBH}_{4}$, ACN, 74\%; (g) LiOH, dioxane $/ \mathrm{H}_{2} \mathrm{O}, 84 \%$; (h) tertbutyl(2aminoethyl)carbamate, HATU, DIPEA, ACN, 94\%; (i) TFA/DCM, 1:1.

The PSMA inhibitor lysine-urea-glutamate $(\mathrm{KuE})$ was synthesized and coupled to 3,4-dibutoxycyclobut-3-en-1,2-dione (SADE) according to Figure 4.<smiles>CC(C)(C)OC(=O)CCC(N)C(=O)OC(C)(C)C</smiles>

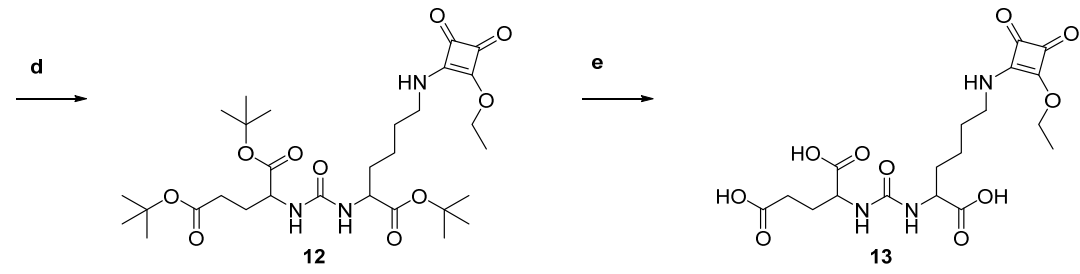

Figure 4. Synthesis of the PSMA inhibitor lysine-urea-glutamate-squaric acid monoester: (a) $N(\varepsilon)$ benzoyloxycarbonyl-L-lysine, triphosgene, triethylamine DCM, $0{ }^{\circ} \mathrm{C}$; (b) L-glutamic acid di-tert-butyl ester hydrochloride, triethylamine, DCM, 41\%; (c) Pd/C, MeOH, $\mathrm{H}_{2}, 96 \%$; (d) 3,4-dibutoxycyclobut3-en-1,2-dione, 0.5 M phosphate buffer $\mathrm{pH}$ 7, ethyl acetate, 77\%; (e) TFA/DCM, 1:1, 83\%.

For the introduction of the urea unit, the amino group of the protected lysine was transformed into an isocyanate using triphosgene. The isocyanate was then reacted with tert-butyl protected glutamate and the protected PSMA inhibitor lysine-urea-glutamate $\mathbf{1 0}$ was obtained and followed by reductive deportation of the lysine side chain, yielding $\mathbf{1 1}$. This compound was then coupled to SADE in phosphate buffer at $\mathrm{pH} 7$. Acidic deprotection 
of the protected compound $\mathbf{1 2}$ led to the couplable PSMA inhibitor lysine-urea-glutamatesquaric acid monoester 13 (KuE.SAME).

The free primary amine of $\operatorname{DATA}^{5 \mathrm{~m}}(\mathbf{9})$ was then coupled to the free coupling side of KuE.SAME (13) in $0.5 \mathrm{M}$ phosphate buffer at $\mathrm{pH} 9$ to obtain the final compound DATA $^{5 \mathrm{~m}}$.SA.KuE (14) (Figure 5).

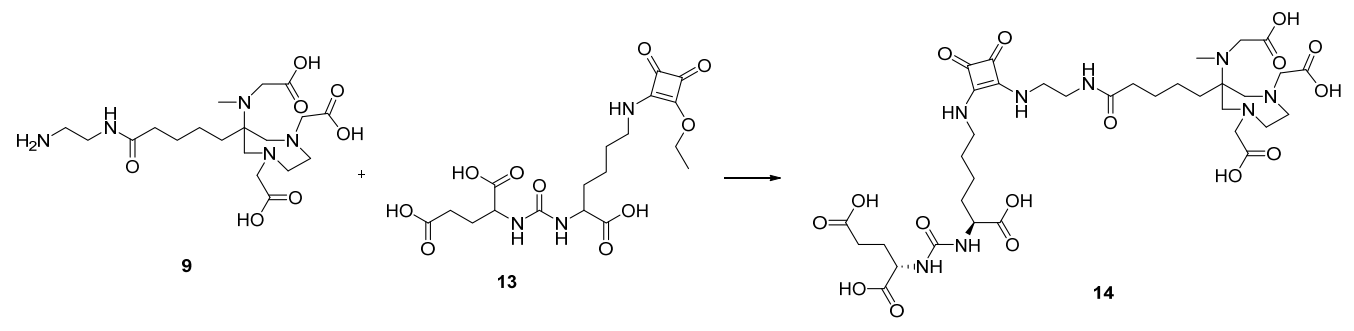

Figure 5. Synthesis of DATA ${ }^{5 \mathrm{~m}}$.SA.KuE (14) $0.5 \mathrm{M}$ phosphate buffer $\mathrm{pH} 9,10 \%$.

\subsubsection{Radiolabeling}

Radiolabeling of AAZTA ${ }^{5}$.SA.KuE with scandium-44 and lutetium-177 was performed according to the literature [17].

DATA $^{5 \mathrm{~m}}$.SA.KuE was radiolabeled with gallium-68 in ammonium acetate buffer (1 M, pH 5.5), varying amounts of precursor (5 nmol to $60 \mathrm{nmol}$ ), and different temperatures (room temperature to $70^{\circ} \mathrm{C}$ ). Labeling was carried out in triplicate with 30-50 MBq of gallium-68. Figure $6 \mathrm{~A}$ shows the kinetic studies of the gallium-68-radiolabeling of DATA $^{5 \mathrm{~m}}$.SA.KuE. The lower the quantity of precursor used, the higher the temperature required to obtain quantitative radiochemical yields (RCY). Labeling of $10 \mathrm{nmol}$ at $50{ }^{\circ} \mathrm{C}$ only achieved a RCY of $56 \%$ after 15 minutes. The increase to $15 \mathrm{nmol}$ at $50{ }^{\circ} \mathrm{C}$ results in quantitative RCY (>99\%). The increase of temperature even allowed the quantitative labeling ( $>99 \% \mathrm{RCY})$ of $5 \mathrm{nmol}$. Furthermore, $50 \mu \mathrm{g}(60 \mathrm{nmol})$ can be radiolabeled in yields of over $99 \%$ with gallium-68 even at room temperature. The high radiochemical yield and high purity of [ $\left.{ }^{68} \mathrm{Ga}\right] \mathrm{Ga}-\mathrm{DATA}{ }^{5 \mathrm{~m}} . \mathrm{SA} . \mathrm{KuE}$ was confirmed by radio-HPLC (Figure $6 \mathrm{~B}$ ).

Studies of the complex stability were performed in human serum (HS) and phosphate buffered saline (PBS). In both media, $\left[{ }^{68} \mathrm{Ga}\right] \mathrm{Ga}-\mathrm{DATA}{ }^{5 \mathrm{~m}}$.SA.KuE showed a stability of $>98 \%$ over a period of 120 minutes (Figure 6C).

\subsection{In Vitro Studies}

\subsubsection{PSMA Binding Affinity}

The PSMA binding affinity of DATA ${ }^{5 \mathrm{~m}}$.SA.KuE and AAZTA ${ }^{5}$.SA.KuE, as well as PSMA-11, was determined in a competitive radioligand assay using PSMA-positive LNCaP cells that were incubated with $0.75 \mathrm{nM}\left[{ }^{68} \mathrm{Ga}\right] \mathrm{Ga}-\mathrm{PSMA}-10$ in the presence of 12 increasing concentrations of the non-labeled SA-conjugated compounds. The measured radioactivity values were plotted against the concentrations of the SA conjugates (Figure 7). $\mathrm{IC}_{50}$ values were determined using GraphPad Prism 9 (Table 1). AAZTA ${ }^{5}$.SA.KuE and DATA $^{5 \mathrm{~m}}$.SA.KuE showed similar binding affinities while PSMA-11 seems to have two-fold higher affinity in vitro.

Table 1. $\mathrm{IC}_{50}$ values of the investigated compounds. Data represented as mean $\pm \mathrm{SD}(\mathrm{n}=3)$.

\begin{tabular}{cc}
\hline Compound & IC $_{\mathbf{5 0}}[\mathbf{n M}]$ \\
\hline DATA $^{5 \mathrm{~m}}$.SA.KuE & $51.1 \pm 5.5$ \\
AAZTA $^{5}$.SA.KuE & $52.1 \pm 4.0$ \\
PSMA-11 $^{-S 4.2}$ & $26.2 \pm 2.4$ \\
\hline
\end{tabular}



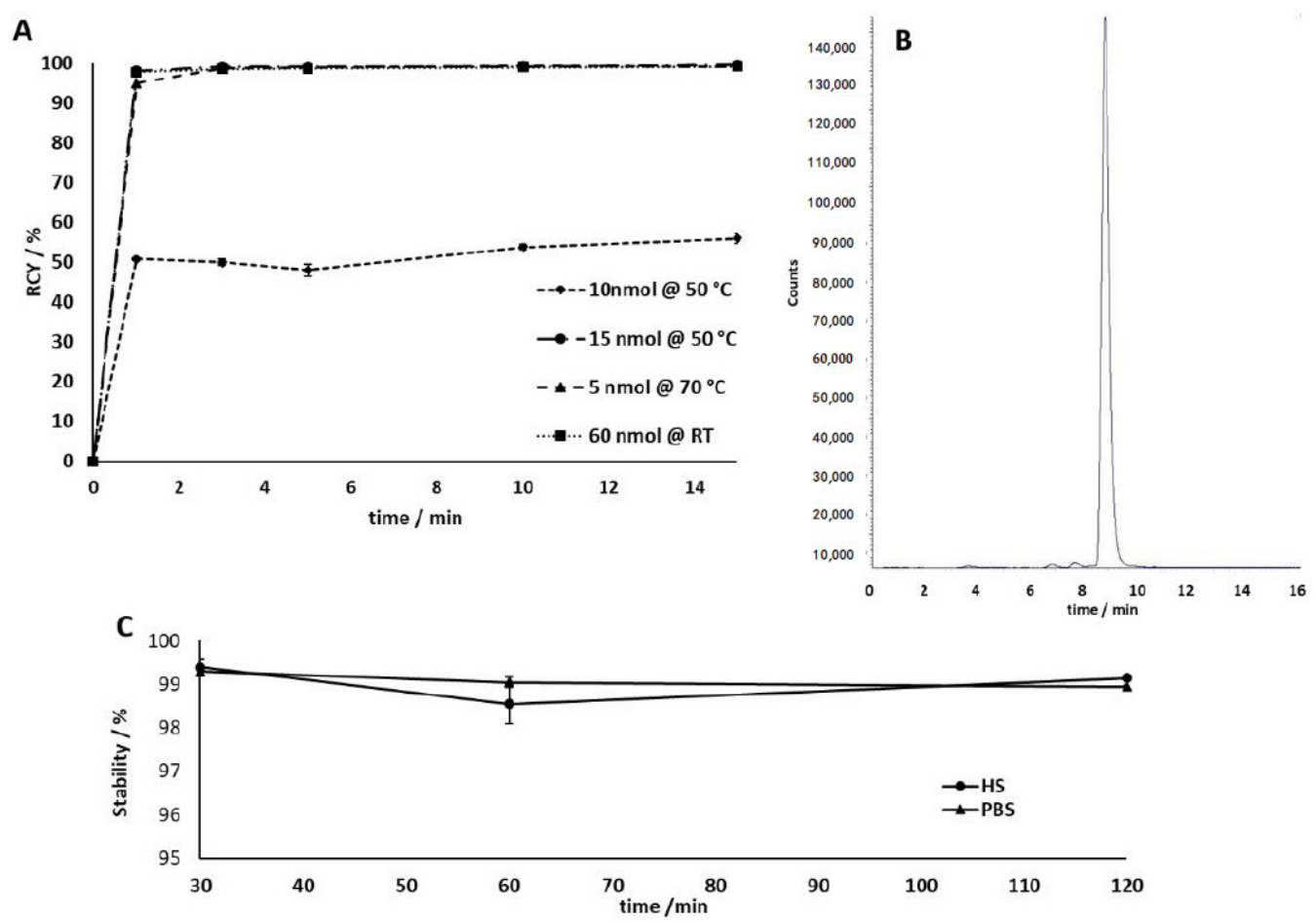

Figure 6. (A) Kinetic studies of ${ }^{68} \mathrm{Ga}$-radiolabeling of DATA ${ }^{5 \mathrm{~m}}$.SA.KuE for various amounts of precursor and different temperatures. Labeling of $15 \mathrm{nmol}$ at $50^{\circ} \mathrm{C}, 5 \mathrm{nmol}$ at $70^{\circ} \mathrm{C}$ and $60 \mathrm{nmol}$ at RT resulting in quantitative RCYs after one minute. Radiolabeling of $10 \mathrm{nmol}$ at $50{ }^{\circ} \mathrm{C}$ results in a RCY of $56 \%$ after 15 minutes. (B) Radio-HPLC of $\left[{ }^{68} \mathrm{Ga}\right] \mathrm{Ga}-\mathrm{DATA}{ }^{5 \mathrm{~m}}$.SA.KuE. $\mathrm{t}_{\mathrm{R}}$ (free gallium-68) = $2.0 \mathrm{~min}$; $\mathrm{t}_{\mathrm{R}}\left(\left[{ }^{68} \mathrm{Ga}\right] \mathrm{Ga}-\mathrm{DATA}{ }^{5 \mathrm{~m}}\right.$.SA.KuE $)=8.8 \mathrm{~min}$. Radio-HPLC confirmed purity and high RCY of $\left[{ }^{68} \mathrm{Ga}\right] \mathrm{Ga}-$ DATA $^{5 \mathrm{~m}}$.SA.KuE. (C) Stability studies for [ $\left.{ }^{68} \mathrm{Ga}\right]$ Ga-DATA ${ }^{5 \mathrm{~m}}$.SA.KuE complex in human serum (HS) and phosphate buffered saline (PBS) of intact conjugate at different time points.

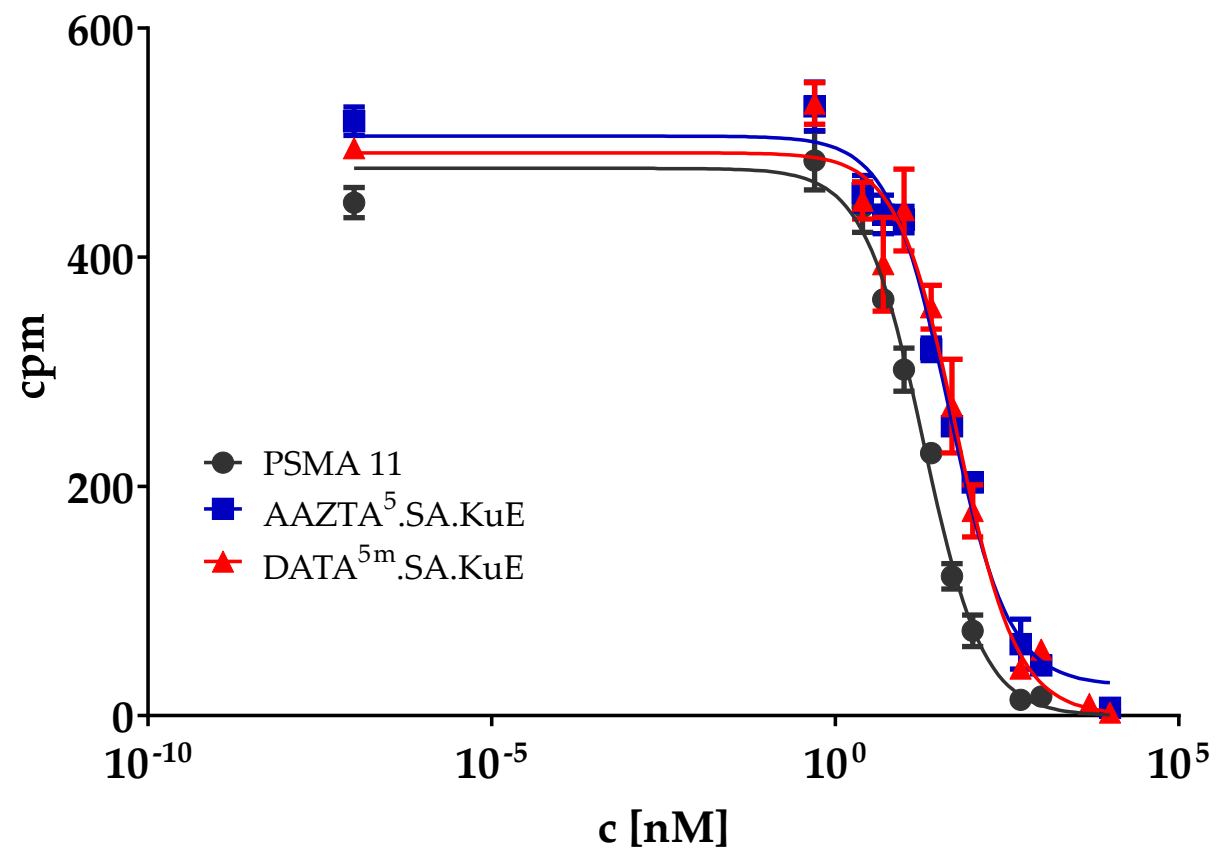

Figure 7. Inhibition curve of AAZTA ${ }^{5}$.SA.KuE, DATA ${ }^{5 \mathrm{~m}}$.SA.KuE and PSMA-11. cpm: counts per minute. 


\subsubsection{Internalization Ratio}

PSMA ligands are internalized upon binding to PSMA, probably via clathrin-mediated endocytosis $[33,34]$. To determine the PSMA-specific cellular uptake of the developed PSMA ligands, we measured both the surface-bound and internalized radioactivity in PSMA-positive LNCaP cells at four different conditions; at $37^{\circ} \mathrm{C}$ with and without blocking with the potent PSMA inhibitor PMPA (2-Phosphonomethyl pentanedioic acid) [35-37], and at $4{ }^{\circ} \mathrm{C}$ with and without blocking with PMPA. Results are plotted in Figure 8. $\left[{ }^{68} \mathrm{Ga}\right] \mathrm{Ga}-$ DATA $^{5 \mathrm{~m}}$.SA.KuE displayed the highest internalization ratio $6.6 \pm 0.6 \%$, whereas the uptake fractions of $\left[{ }^{44} \mathrm{Sc}\right] \mathrm{Sc}-\mathrm{AAZTA}{ }^{5}$.SA.KuE and $\left[{ }^{68} \mathrm{Ga}\right] \mathrm{Ga}$-PSMA-11 were slightly lower (4.8\% and $5.2 \%$, respectively). PSMA-specific uptake was mainly reduced at $4{ }^{\circ} \mathrm{C}$.

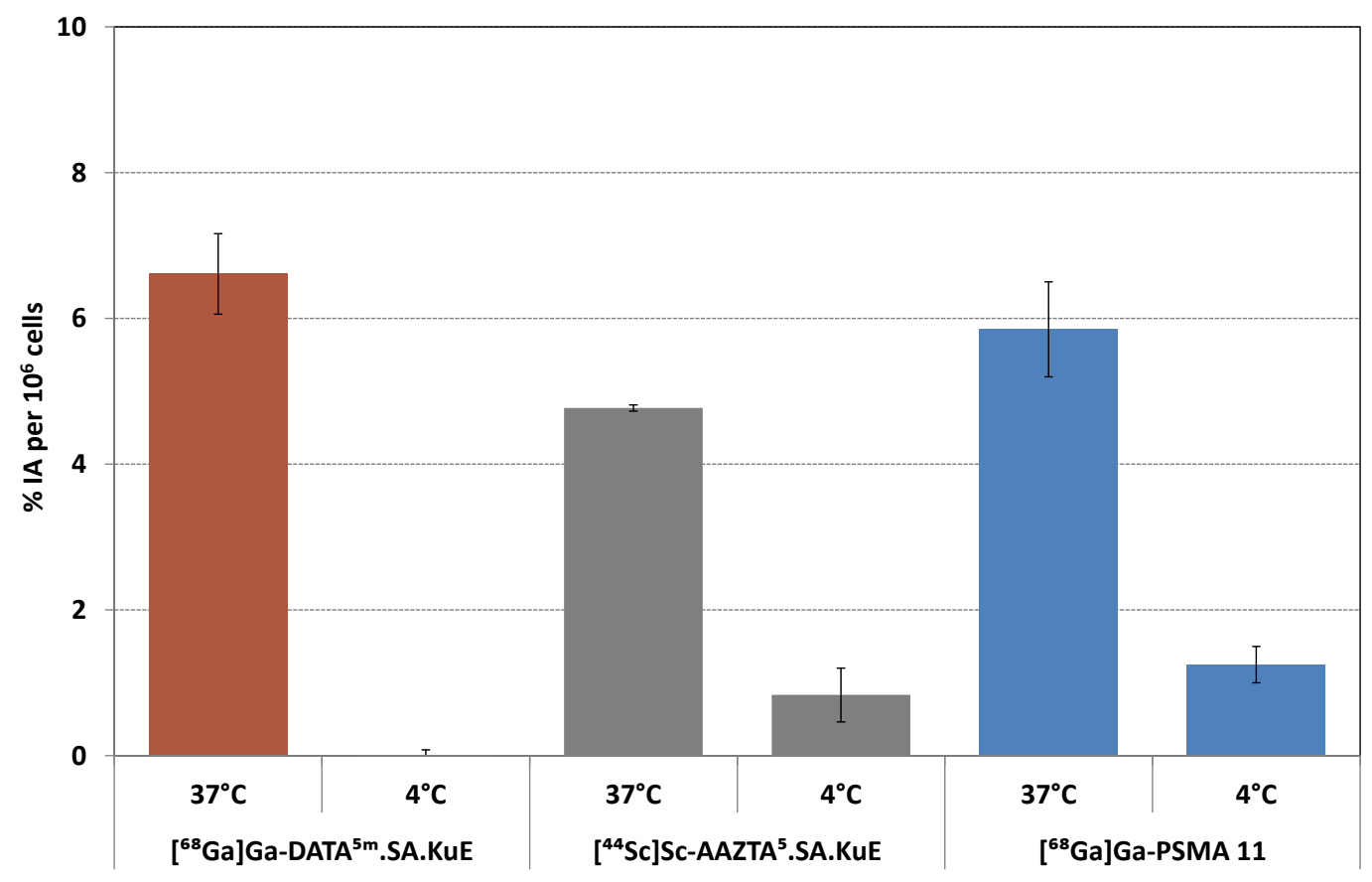

Figure 8. Internalization ratio of $\left[{ }^{68} \mathrm{Ga}\right] \mathrm{Ga}-\mathrm{DATA}{ }^{5 \mathrm{~m}}$.SA.KuE and $\left[{ }^{44} \mathrm{Sc}\right] \mathrm{Sc}-\mathrm{AAZTA}{ }^{5} . \mathrm{SA} . \mathrm{KuE}$ with $\left[{ }^{68} \mathrm{Ga}\right] \mathrm{Ga}-\mathrm{PSMA}-11$ as reference; $\%$ injected dose per $10^{6} \mathrm{LNCaP}$ cells.

\subsection{Animal Studies}

In order to evaluate the in vivo behavior of the SA.KuE conjugates, an LNCaP-xenograft model was used. Labeling of AAZTA ${ }^{5}$.SA.KuE with the different nuclides scandium- 44 and lutetium-177 seemed to have no impact on the pharmacokinetic properties of the conjugates, since there were no significant differences observed in the biodistribution data (Figure 9). Tumor accumulation values of all four compounds were similar, $3.92 \pm 0.50 \% \mathrm{ID} / \mathrm{g}$, $5.41 \pm 0.83 \% \mathrm{ID} / \mathrm{g}, 4.43 \pm 0.56 \% \mathrm{ID} / \mathrm{g}$ and $5.52 \pm 0.75 \% \mathrm{ID} / \mathrm{g}$ for $\left[{ }^{44} \mathrm{Sc}\right] \mathrm{Sc}-\mathrm{AAZTA}{ }^{5}$.SA.KuE, $\left[{ }^{177} \mathrm{Lu}\right] \mathrm{Lu}-\mathrm{AAZTA}{ }^{5} . \mathrm{SA} \cdot \mathrm{KuE},\left[{ }^{68} \mathrm{Ga}\right] \mathrm{Ga}-\mathrm{DATA}{ }^{5 \mathrm{~m}}$.SA.KuE and $\left[{ }^{68} \mathrm{Ga}\right] \mathrm{Ga}-\mathrm{PSMA}-11$ respectively. The higher kidney uptake of $\left[{ }^{68} \mathrm{Ga}\right] \mathrm{Ga}-\mathrm{PSMA}-11(73.39 \pm 18.77 \% \mathrm{ID} / \mathrm{g})$ is noteworthy compared to the uptake of the SA.KuE conjugates $(20.69 \pm 7.24 \% \mathrm{ID} / \mathrm{g}, 22.70 \pm 0.90 \% \mathrm{ID} / \mathrm{g}$, $13.63 \pm 6.81 \% \mathrm{ID} / \mathrm{g}$ for $\left[{ }^{44} \mathrm{Sc}\right] \mathrm{Sc}-\mathrm{AAZTA}{ }^{5 \mathrm{~m}}$.SA.KuE, $\left[{ }^{177} \mathrm{Lu}\right] \mathrm{Lu}-\mathrm{AAZTA}{ }^{5 \mathrm{~m}} . \mathrm{SA} . \mathrm{KuE}$ and $\left[{ }^{68} \mathrm{Ga}\right] \mathrm{Ga}-\mathrm{DATA}{ }^{5}$.SA.KuE respectively). Both tumor and kidney uptake of $\left[{ }^{68} \mathrm{Ga}\right] \mathrm{Ga}-$ DATA ${ }^{5}$.SA.KuE were found to be PSMA-specific, since they could be blocked by coinjection of PMPA as seen in Figure 10. 


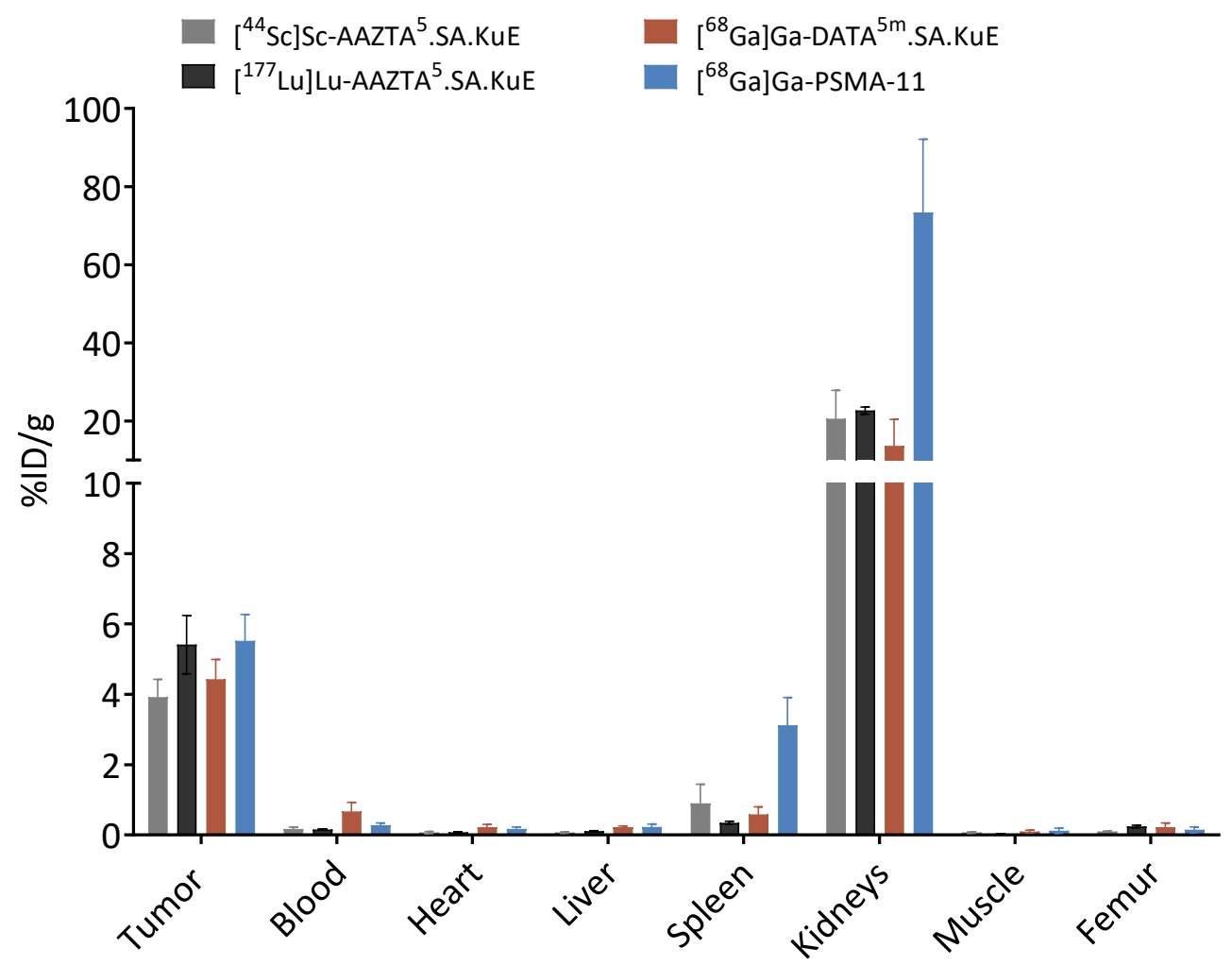

Figure 9. Ex vivo biodistribution data of $\left[{ }^{44} \mathrm{Sc}\right] \mathrm{Sc}-\mathrm{AAZTA}{ }^{5} . \mathrm{SA} . \mathrm{KuE},\left[{ }^{177} \mathrm{Lu}\right] \mathrm{Lu}-\mathrm{AAZTA}{ }^{5} . \mathrm{SA} . \mathrm{KuE}$, $\left[{ }^{68} \mathrm{Ga}\right] \mathrm{Ga}-\mathrm{DATA}{ }^{5 \mathrm{~m}}$.SA.KuE and $\left[{ }^{68} \mathrm{Ga}\right] \mathrm{Ga}-\mathrm{PSMA}-11 \mathrm{in} \mathrm{LNCaP}$ tumor-bearing Balb/c nude mice $1 \mathrm{~h}$ p.i. \%ID/g: \% injected dose per gram. Values are mean \pm SD.

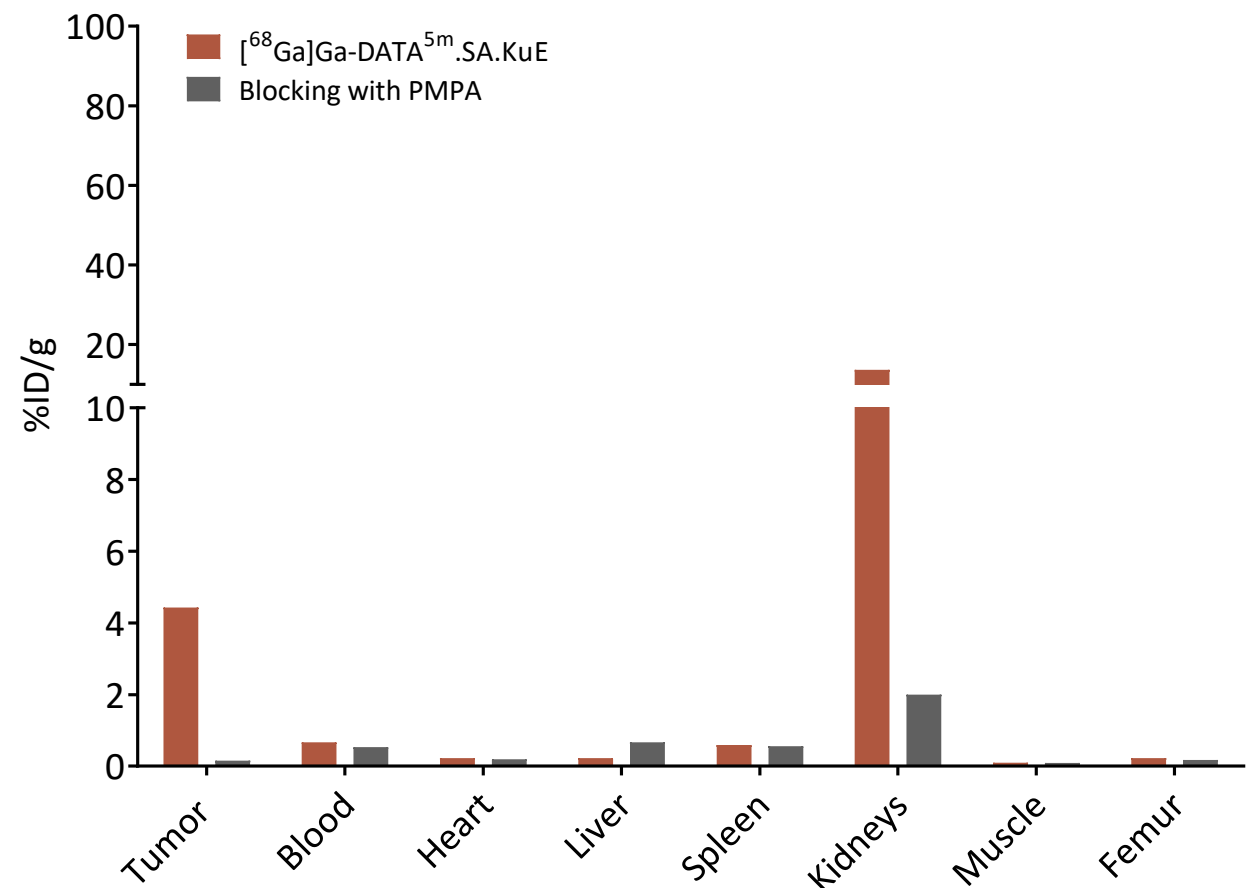

Figure 10. Ex vivo biodistribution of $\left[{ }^{68} \mathrm{Ga}\right] \mathrm{Ga}-\mathrm{DATA}{ }^{5 \mathrm{~m}}$.SA.KuE compared to organ accumulation after co-injection with an access PMPA.

To further understand the pharmacokinetics of the developed PSMA ligands, we performed $\mu$ PET-scans with the same xenograft model (Figure 11). Tumor accumulation of all three compounds was very similar. The kidney uptake of $\left[{ }^{68} \mathrm{Ga}\right] \mathrm{Ga}-\mathrm{DATA}{ }^{5}$.SA.KuE 
was remarkably lower than the reference compound $\left[{ }^{68} \mathrm{Ga}\right] \mathrm{Ga}-\mathrm{PSMA}-11$. This finding correlates with the results obtained from the time-activity curves of both compounds (Figure 12). Herein, the radioactivity concentration of $\left[{ }^{68} \mathrm{Ga}\right] \mathrm{Ga}-\mathrm{DATA}{ }^{5 \mathrm{~m}}$.SA.KuE decreased continuously $10 \mathrm{~min}$ p.i. while the concentration in the tumor remained constant. However, the radioactivity concentration of $\left[{ }^{68} \mathrm{Ga}\right] \mathrm{Ga}$-PSMA-11 remained at a higher level during the period of the scan. As demonstrated in the $\mu$ PET scans, uptake in the tumor as well as in the kidney was PSMA-specific. After co-injection of PMPA, almost no radioactivity could be detected (Figure 11).

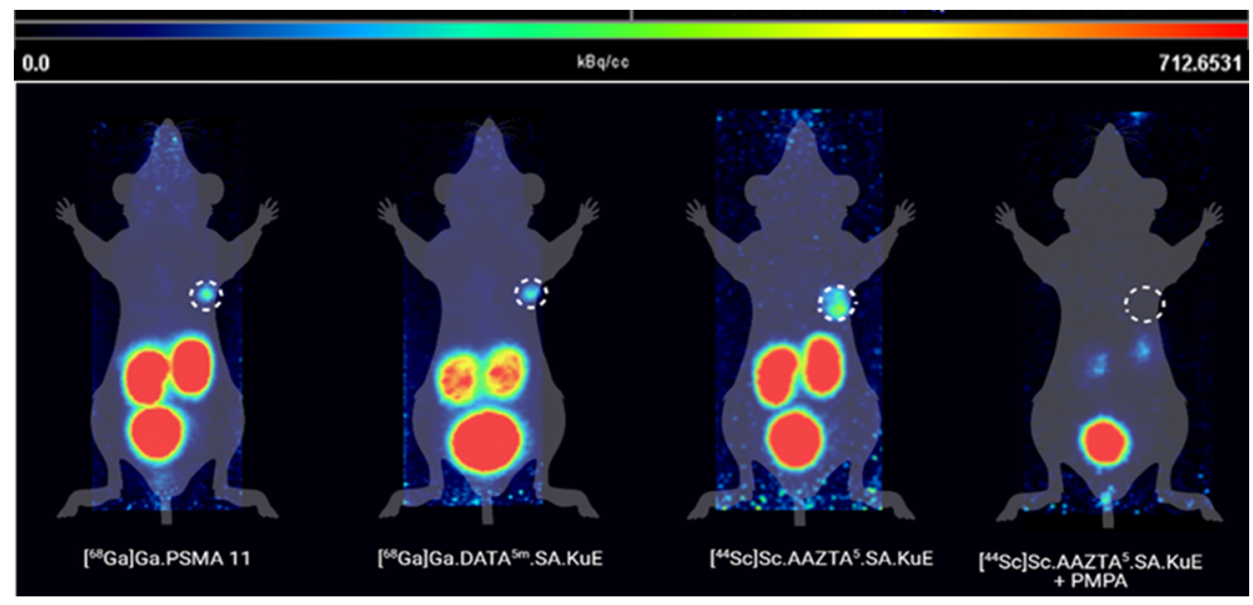

(a)

(b)

(c)

(d)

Figure 11. Maximum intensity projections of $\mu$ PET scans $1 \mathrm{~h}$ p.i. of (a) $\left[{ }^{68} \mathrm{Ga}\right] \mathrm{Ga}-\mathrm{PSMA}-11$, (b) $\left[{ }^{68} \mathrm{Ga}\right] \mathrm{Ga}-\mathrm{DATA}{ }^{5 \mathrm{~m}}$.SA.KuE, (c) $\left.{ }^{44} \mathrm{Sc}\right] \mathrm{Sc}-\mathrm{AAZTA}{ }^{5}$.SA.KuE and (d) co-injection of $\left[{ }^{44} \mathrm{Sc}\right] \mathrm{Sc}-$ AZTA ${ }^{5}$.SA.KuE and PMPA (tumor circled).

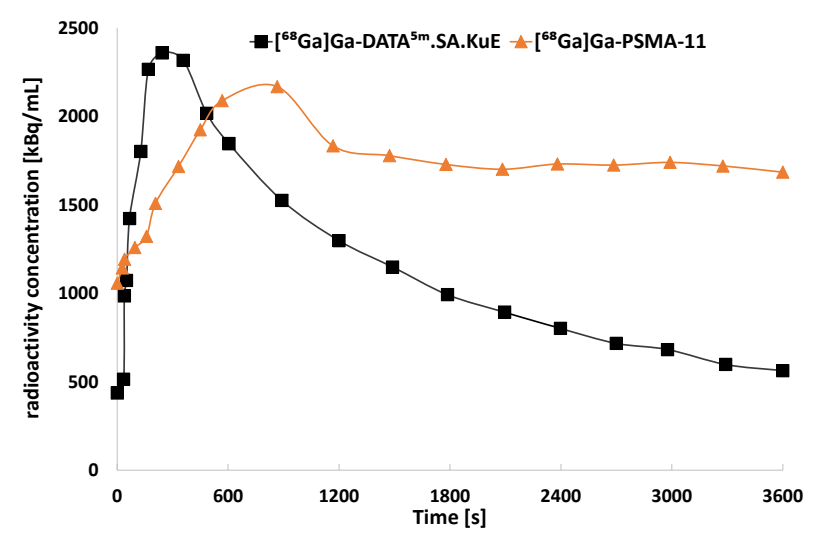

(a)

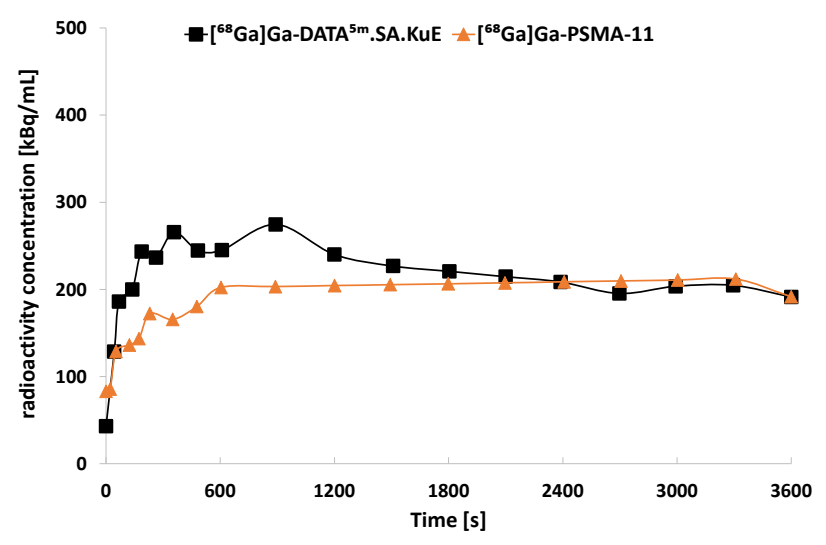

(b)

Figure 12. Time-activity curves of the uptake of $\left[{ }^{68} \mathrm{Ga}\right] \mathrm{Ga}-\mathrm{DATA}{ }^{5 \mathrm{~m}} \cdot \mathrm{SA} \cdot \mathrm{KuE}$ and $\left[{ }^{68} \mathrm{Ga}\right] \mathrm{Ga}-\mathrm{PSMA}-11$ in the kidneys (a) and the tumor $(\mathbf{b})$ over the total period of the $\mu$ PET scan.

\section{Discussion}

The discovery of PSMA as molecular target in the diagnosis and therapy of prostate cancer, as well as the application of radiolabeled PSMA inhibitors, have revolutionized the management of this disease resulting in a significant improvement especially in staging and assessment of prostate cancer [38]. Although several PSMA ligands have been developed over the last decades, the search for novel tracers with optimized pharmacokinetic properties particularly for therapeutic purposes is still present, since some of the clinically used PSMA radioligand therapeutics e.g., [225 Ac]Ac-PSMA-617 display some severe side effects, like xerostomia [12,13,39]. 
To determine the effect of the chelator on the PSMA binding affinity and the internalization ratio of PSMA ligands, we synthesized two PSMA inhibitors with different hybrid chelators. In the cell-based assays, both DATA ${ }^{5 \mathrm{~m}} \cdot \mathrm{SA} . \mathrm{KuE}$ and AAZTA ${ }^{5}$.SA.KuE showed similar binding affinity and internalization ratios, indicating that an exchange of DATA ${ }^{5 \mathrm{~m}}$ against AAZTA ${ }^{5}$ had no impact on either the binding affinity or on the internalization ratio in PSMA-positive LNCaP cells. These findings correlate with the results published by Sinnes et al., who investigated the influence of the exchange of DOTA chelator in DOTA-PSMA-617 against AAZTA ${ }^{5}$. Both DOTA-PSMA-617 and AAZTA ${ }^{5}$-PSMA-617 displayed similar in vitro binding affinities and internalization ratios in LNCaP cells [40]. However, the reported binding affinities and internalization ratios of AATA ${ }^{5}$-PSMA-617 and DOTA-PSMA-617 were higher than those of the SA.KuE conjugates. In particular, [ ${ }^{44}$ Sc]Sc-PSMA-617 seems to display high PSMA-binding affinity as published by several groups [41,42]. Since PSMA-617 was not commercially available at the time this study was performed, PSMA-11 was used as reference.

However, PSMA-11 displayed also higher binding affinity in vitro which could be due to the better interaction with the PSMA binding pocket. In contrast, the internalization ratio of PSMA-11 was similar to these of the SA.KuE-conjugates. Interestingly, the investigated internalization fraction of $\left[{ }^{68} \mathrm{Ga}\right] \mathrm{Ga}-\mathrm{PSMA}-11$ was noticeably lower compared to the ratio described in literature [42,43] which could be due to differences in study design and setup. The PSMA-specificity of binding and uptake in LNCaP cells and LNCaP tumors could be demonstrated for all herein investigated PSMA-inhibitors by blocking PSMA receptors with the potent inhibitor PMPA.

In order to evaluate the pharmacokinetic behavior of our compounds and to compare them with PSMA-11, we performed animal studies using an LNCaP xenograft model.

AAZTA ${ }^{5}$.SA.KuE was labeled with the positron emitter scandium-44 and $\beta^{-}$emitterlutetium-177. Both radiotracers displayed similar biodistribution data, indicating that both isotopes do not impact the pharmacokinetic properties of the PSMA radioligand. This result makes this pair ideal for theranostic use. In addition, $\left[{ }^{68} \mathrm{Ga}\right] \mathrm{Ga}-\mathrm{DATA}{ }^{5 \mathrm{~m}}$.SA.KuE equally showed a promising biodistribution profile and a good imaging contrast. Surprisingly, although PSMA-11 showed a two-fold higher binding affinity in vitro, tumor accumulation was similar to the SA.KuE-conjugates. Furthermore, the kidney uptake of $\left[{ }^{68} \mathrm{Ga}\right] \mathrm{Ga}-\mathrm{PSMA}-11$ was significantly higher than the SA.KuE-conjugated compounds. $\left[{ }^{68} \mathrm{Ga}\right] \mathrm{Ga}-\mathrm{DATA}{ }^{5 \mathrm{~m}}$.SA.KuE, $\left[{ }^{44} \mathrm{Sc}\right] \mathrm{Sc}-\mathrm{AAZTA}{ }^{5}$.SA.KuE and $\left[{ }^{177} \mathrm{Lu}\right] \mathrm{Lu}-\mathrm{AAZTA}{ }^{5}$.SA.KuE. Thus, these compounds seem to display a rapid renal clearance along with a good tumor accumulation. However, the tumor uptake of the SA.KuE conjugates was lower than that of the gallium-68 and lutetium-177 labeled PSMA-617 radioligands [10,11]. Ghiani et al. recently described a novel scandium-44 labeled PSMA radioligand with even higher tumor accumulation than the PSMA-617 counterpart [41]. Nevertheless, a direct comparison between the presented results and those reported by other groups is not possible because of the differences in xenograft models and experimental setups.

\section{Materials and Methods}

\subsection{General}

All chemicals were purchased from Sigma-Aldrich (St. Louis, MO, USA), Merck (Kenilworth, NJ, USA), Fluka (Buchs, Switzerland), AlfaAesar (Haverhill, MA, USA), VWR (Radnor, PA, USA), AcrosOrganics (Geel, Belgium), TCI (Portland, OR, USA), Iris Biotech (Marktredwitz, Germany) and Fisher Scientific (Hampton, NH, USA) and used without purification. Dry solvents were obtained from Merck and VWR, deuterated solvents for NMR spectra from Deutero. Thin layer chromatography was performed with silica gel 60 F254 coated aluminum plates from Merck. Evaluation was carried out by fluorescence extinction at $\lambda=254 \mathrm{~nm}$ and staining with potassium permanganate. The radio TLCs were evaluated using a CR-35 Bio test imager (Elysia-Raytest, Angleur, Belgium) from Raytest and the AIDA software (Elysia-Raytest, Angleur, Belgium). The ${ }^{1} \mathrm{H}$ and ${ }^{13} \mathrm{C}$ NMR measurements were performed on an Avance III HD 300 spectrometer (Bruker 
Corporation, Billerica, MA, USA) (300 MHz, 5mm BBFO sample head with z-gradient and ATM and BACS 60 sample changer), an Avance II 400 (Bruker Corporation, Billerica, MA, USA) (400 MHz, 5 mm BBFO sample head with z-Gradient and ATM and SampleXPress 60 sample changer), and an Avance III 600 spectrometer (Bruker Corporation, Billerica, MA, USA) (600 MHz, 5mm TCI CryoProbe sample head with z-Gradient and ATM and SampleXPress Lite 16 sample changer). The LC/MS measurements were performed on an Agilent Technologies 1220 Infinity LC system coupled to an Agilent Technologies 6130B Single Quadrupole LC/MS system. Semi-preparative HPLC purification was performed on a 7000 series Hitachi LaChrom (Hitachi, Chiyoda, Japan).

\subsection{Organic Synthesis}

DATA $^{5 \mathrm{~m}}$ was synthesized according to the procedure described by Farkas et al. and Greifenstein et al. [17].

$N, N^{\prime}$-Dibenzyl- $N, N^{\prime}$-di-(tert-butylacetate)-ethylendiamine (1)

$N, N^{\prime}$-dibenzylethylendiamine $(2.90 \mathrm{~mL}, 3.00 \mathrm{~g}, 12.50 \mathrm{mmol})$ and sodium carbonate $(5.10 \mathrm{~g}, 48.70 \mathrm{mmol})$ were dissolved in acetonitrile $(50 \mathrm{~mL})$ and stirred for $30 \mathrm{~min}$ at room temperature. Tert-butyl bromoacetate $(3.60 \mathrm{~mL}, 4.60 \mathrm{~g}, 23.70 \mathrm{mmol})$ in acetonitrile $(10 \mathrm{~mL})$ was added dropwise at room temperature. The reaction mixture was stirred overnight at $90^{\circ} \mathrm{C}$ and filtered. The solvent was evaporated under reduced pressure. The product was purified by column chromatography (hexane/ethyl acetate; $6: 1, R_{\mathrm{f}}=0.37$ ) and obtained as a colorless solid (5.73 g, $12.2 \mathrm{mmol}, 96 \%)$.

${ }^{1} \mathrm{H}-\mathrm{NMR}\left(400 \mathrm{MHz}, \mathrm{CDCl}_{3}\right): \delta[\mathrm{ppm}]=7.34-7.21(\mathrm{~m}, 10 \mathrm{H}), 3.78(\mathrm{~s}, 4 \mathrm{H}), 3.26(\mathrm{~s}, 4 \mathrm{H})$, $2.82(\mathrm{~s}, 4 \mathrm{H}), 1.44(\mathrm{~s}, 18 \mathrm{H})$.

${ }^{13} \mathrm{C}-\mathrm{NMR}(400 \mathrm{MHz}, \mathrm{CDCl} 3): \delta[\mathrm{ppm}]=171.03,139.18,129.05,128.30,127.10,80.86$, $58.39,55.27,51.73,28.24$.

MS (ESI ${ }^{+}$): $469.4[\mathrm{M}+\mathrm{H}]^{+}$, calculated for $\mathrm{C}_{28} \mathrm{H}_{40} \mathrm{~N}_{2} \mathrm{O}_{4}: 468.30[\mathrm{M}]^{+}$.

$\mathrm{N}, \mathrm{N}^{\prime}$-di-(tert-butylacetate)-ethylendiamine (2)

Product 1 ( $2.3 \mathrm{~g} ; 5.60 \mathrm{mmol})$ was dissolved in abs ethanol $(15 \mathrm{~mL})$ and formic acid $(0.43 \mathrm{~mL}, 0.52 \mathrm{~g}, 11.0 \mathrm{mmol})$. To this solution palladium on activated carbon ( $416 \mathrm{mg}$, $16 \% \mathrm{wt}$ ) was added and the solution was saturated, kept and stirred overnight with hydrogen. Pd/C was filtered over celite and the solvent was evaporated under reduced pressure. The product $(1.58 \mathrm{mg}, 5.5 \mathrm{mmol}, 98 \%)$ was used without further purification.

MS $\left(\mathrm{ESI}^{+}\right): 289.3[\mathrm{M}+\mathrm{H}]^{+}$, calculated for $\mathrm{C}_{14} \mathrm{H}_{28} \mathrm{~N}_{2} \mathrm{O}_{4}: 288.36[\mathrm{M}]^{+}$.

1,4-Di(tert-butylacetate)-6-methyl-6-nitroperhydro-1,4-diazepane (3)

2-Nitrocyclohexanone $\left(1.70 \mathrm{~g}, 12 \mathrm{mmol}\right.$ ) and Amberlyst ${ }^{\circledR}$ A21 (2 mass equivalents) were dissolved in methanol $(30 \mathrm{ml})$ and stirred at $90^{\circ} \mathrm{C}$ for $1 \mathrm{~h}$. Paraformaldehyde $(1.30 \mathrm{~g}$, $42.3 \mathrm{mmol})$ and Product (2) $(3.50 \mathrm{~g}, 12 \mathrm{mmol})$ were added. The solution was heated overnight under reflux. The solvent was evaporated under reduced pressure. The product was purified by column chromatography (hexane/ethyl acetate; $2: 1, \mathrm{R}_{\mathrm{f}}=0.33$ ) and obtained as a yellowish oil ( $4.52 \mathrm{~g}, 9.28 \mathrm{mmol}, 77 \%)$.

${ }^{1} \mathrm{H}-\mathrm{NMR}\left(400 \mathrm{MHz}, \mathrm{CDCl}_{3}\right): \delta[\mathrm{ppm}]=3.65(\mathrm{~s}, 3 \mathrm{H}), 3.60(\mathrm{~d}, J=14,6 \mathrm{~Hz}, 2 \mathrm{H}), 3.45(\mathrm{~d}$, $J=17.3 \mathrm{~Hz}, 2 \mathrm{H}), 3.30(\mathrm{~d}, J=17.3 \mathrm{~Hz}, 2 \mathrm{H}), 3.12(\mathrm{~d}, J=14.6 \mathrm{~Hz}, 2 \mathrm{H}), 2.84(\mathrm{~m}, 4 \mathrm{H}), 2.27(\mathrm{t}, 2 \mathrm{H})$, $1.83(\mathrm{~m}, 2 \mathrm{H}), 1.57(\mathrm{~m}, 2 \mathrm{H}), 1.46(\mathrm{~s}, 18 \mathrm{H}), 1.18(\mathrm{~m}, 2 \mathrm{H})$.

${ }^{13} \mathrm{C}-\mathrm{NMR}\left(400 \mathrm{MHz}, \mathrm{CDCl}_{3}\right): \delta[\mathrm{ppm}]=173.73,170.92,95.12,81.31,61.57,61.18,56.87$, $51.68,37.27,33.71,28.35,24.82,22.99$.

MS (ESI ${ }^{+}$): $488.3[\mathrm{M}+\mathrm{H}]^{+}$, calculated for $\mathrm{C}_{23} \mathrm{H}_{41} \mathrm{~N}_{3} \mathrm{O}_{8}: 487.29[\mathrm{M}]^{+}$.

1,4-Di(tert-butylacetate)-6-methylpentanoate-6-amino-perhydro-1,4-diazepane (4)

Compound 3 ( $4.50 \mathrm{~g}, 9.30 \mathrm{mmol})$ was dissolved in abs. ethanol $(40 \mathrm{~mL})$. Raney ${ }^{\circledR}$ nickel was added and the solution was saturated, kept and stirred for four days with hydrogen at $40{ }^{\circ} \mathrm{C}$. The nickel was filtered over celite and the solvent was evaporated under reduced pressure. Compound $4(3.92 \mathrm{~g}, 8.60 \mathrm{mmol}, 72 \%)$, was obtained as a greenish oil and used without further purification.

MS $\left(\mathrm{ESI}^{+}\right): 458.3[\mathrm{M}+\mathrm{H}]^{+}$, calculated for $\mathrm{C}_{23} \mathrm{H}_{43} \mathrm{~N}_{3} \mathrm{O}_{6}: 457.32[\mathrm{M}]^{+}$. 
1,4-Di(tert-butylacetate)-6-methylpentonate-6-amino-tert-butylacetate-perhydro-1,4diazepane (5)

Compound $4(1.30 \mathrm{~g}, 2.84 \mathrm{mmol})$ and $N, N$-diisopropylethylamine $(483 \mu \mathrm{L}, 367 \mathrm{mg}$, $2.84 \mathrm{mmol})$ were dissolved in dry acetonitrile $(20 \mathrm{~mL})$ and stirred for $20 \mathrm{~min}$ at room temperature. Tert-butyl bromoacetate $(538 \mu \mathrm{L}, 720 \mathrm{mg}, 3.69 \mathrm{mmol})$ was added dropwise and stirred overnight at room temperature. The solvent was evaporated under reduced pressure. The product was purified by column chromatography (cyclohexane/ethyl acetate; $3: 1+3 \%$ trimethylamine, $\left.R_{\mathrm{f}}=0.34\right)$ and obtained as a yellowish oil $(1.01 \mathrm{~g}, 1.77 \mathrm{mmol}, 62 \%)$.

${ }^{1} \mathrm{H}-\mathrm{NMR}\left(400 \mathrm{MHz}, \mathrm{CDCl}_{3}\right): \delta[\mathrm{ppm}]=3.65(\mathrm{~s}, 3 \mathrm{H}), 3.29(\mathrm{~s}, 4 \mathrm{H}), 3.21(\mathrm{~s}, 2 \mathrm{H})$, 2.83-2.60 (m, 8H), $2.30(\mathrm{dd}, J=8.9,6.3 \mathrm{~Hz}, 2 \mathrm{H}), 1.90(\mathrm{~s} \mathrm{br}, 1 \mathrm{H}), 1.62-1.54(\mathrm{~m}, 2 \mathrm{H}), 1.46(\mathrm{~s}, 9 \mathrm{H})$, $1.44(\mathrm{~s}, 18 \mathrm{H}), 1.32-1.23(\mathrm{~m}, 4 \mathrm{H})$.

MS $\left(\mathrm{ESI}^{+}\right): 572.4[\mathrm{M}+\mathrm{H}]^{+}$, calculated for $\mathrm{C}_{29} \mathrm{H}_{53} \mathrm{~N}_{3} \mathrm{O}_{8}: 571.38[\mathrm{M}]^{+}$.

1,4-Di(tert-butylacetate)-6-methylpentonate-6-(amino(methyl)-tert-butylacetate)-perhydro1,4 diazepane (6)

Compound 5 (1.00 g, $1.75 \mathrm{mmol})$, formalin solution $(482 \mu \mathrm{L}, 526 \mathrm{mg}, 6.47 \mathrm{mmol})$, and acetic acid $(300 \mu \mathrm{L}, 315 \mathrm{mg}, 5.25 \mathrm{mmol})$ were dissolved in dry acetonitrile $(20 \mathrm{~mL})$ and stirred at room temperature for $30 \mathrm{~min}$. Sodium borhydride $(200 \mathrm{mg}, 5.29 \mathrm{mmol})$ was added portion-wise over $30 \mathrm{~min}$. The reaction solution was stirred for 2 hours at room temperature. Water $(25 \mathrm{~mL})$ was added and extracted with chloroform $(4 \times 50 \mathrm{~mL})$. The organic phase was separated and dried over sodium sulfate and evaporated under reduced pressure. The product was purified by column chromatography (cyclohexane/ethyl acetate; $5: 1+2 \%$ trimethylamine, $\left.R_{f}=0.28\right)$ and obtained as colorless oil $(0.76 \mathrm{~g}, 1.39 \mathrm{mmol}, 74 \%)$.

${ }^{1} \mathrm{H}-\mathrm{NMR}\left(400 \mathrm{MHz}, \mathrm{CDCl}_{3}\right): \delta[\mathrm{ppm}]=3.65(\mathrm{~s}, 3 \mathrm{H}), 3.42(\mathrm{~s}, 2 \mathrm{H}), 3.32-3.18(\mathrm{~m}, 4 \mathrm{H})$, $2.93(\mathrm{~d}, J=14.0 \mathrm{~Hz}, 2 \mathrm{H}), 2.83-2.73(\mathrm{~m}, 2 \mathrm{H}), 2.70-2.58(\mathrm{~m}, 4 \mathrm{H}), 2.35-2.24(\mathrm{~m}, 5 \mathrm{H}), 1.63-1.48(\mathrm{~m}$, $4 \mathrm{H}), 1.45(\mathrm{~s}, 9 \mathrm{H}), 1.44(\mathrm{~s}, 18 \mathrm{H}), 1.41-1.22(\mathrm{~m}, 2 \mathrm{H})$.

MS $\left(\mathrm{ESI}^{+}\right): 586.4[\mathrm{M}+\mathrm{H}]^{+}$, calculated for $\mathrm{C}_{30} \mathrm{H}_{55} \mathrm{~N}_{3} \mathrm{O}_{8}: 585.40[\mathrm{M}]^{+}$.

1,4-Di(tert-butylacetate)-6-pentanoicacid-6-(amino(methyl)-tert-butylacetate)-perhydro1,4-diazepane (7)

Compound 6 (0.75 g, $1.28 \mathrm{mmol})$ was dissolved in a 1,4-dioxane/water (2:1) mixture. Then, $1 \mathrm{M}$ lithium hydroxide solution $(1.92 \mathrm{~mL}, 1.92 \mathrm{mmol})$ was added and stirred for 7 days. After 2, 4, and 6 days $1 \mathrm{M}$ lithium hydroxide solution $(0.32 \mathrm{~mL}, 0.32 \mathrm{mmol})$ was added. 1,4-dioxane was evaporated under reduced pressure. The remaining water phase was extracted with chloroform $(5 \times 50 \mathrm{~mL})$. The organic phase was washed with $1 \mathrm{M}$ sodium hydrogen carbonate solution $(25 \mathrm{~mL})$ and brine $(2 \times 25 \mathrm{~mL})$ and dried over sodium sulfate and evaporated under reduced pressure. The product (615 mg, $1.07 \mathrm{mmol}, 84 \%)$ was obtained as a yellowish oil.

${ }^{1} \mathrm{H}-\mathrm{NMR}\left(400 \mathrm{MHz}, \mathrm{CDCl}_{3}\right): \delta[\mathrm{ppm}]=3.44(\mathrm{~s}, 2 \mathrm{H}), 3.25(\mathrm{~d}, J=2.2 \mathrm{~Hz}, 4 \mathrm{H}), 2.93(\mathrm{~d}$, $J=14.0 \mathrm{~Hz}, 2 \mathrm{H}), 2.82-2.73(\mathrm{~m}, 2 \mathrm{H}), 2.71-2.61(\mathrm{~m}, 4 \mathrm{H}), 2.34(\mathrm{t}, J=7.7 \mathrm{~Hz}, 2 \mathrm{H}), 2.27(\mathrm{~s}, 3 \mathrm{H})$, $1.65-1.51(\mathrm{~m}, 4 \mathrm{H}), 1.45(\mathrm{~s}, 18 \mathrm{H}), 1.44(\mathrm{~s}, 9 \mathrm{H}), 1.43-1.21(\mathrm{~m}, 2 \mathrm{H})$.

${ }^{13} \mathrm{C}-\mathrm{NMR}\left(400 \mathrm{MHz}, \mathrm{CDCl}_{3}\right): \delta[\mathrm{ppm}]=178.46,172.53,170.98,81.02,80.44,77.36,62.86$, $62.59,62.48,59.02,54.21,37.49,36.92,34.17,28.37,28.27,25.71,21.97$.

MS $\left(\mathrm{ESI}^{+}\right): 572.4[\mathrm{M}+\mathrm{H}]^{+}$, calculated for $\mathrm{C}_{29} \mathrm{H}_{53} \mathrm{~N}_{3} \mathrm{O}_{8}: 571.38[\mathrm{M}]^{+}$.

1,4-Di(tert-butylacetate)-6-((5-(2-((2-ethoxy-3,4-dioxocyclobut-1-en-1yl)amino-ethyl)amino)5-oxopentyl)-6-(amino(methyl)-tert-butylacetate)-perhydro-1,4-diazepane (8)

Compound 7 (100 mg, $0.175 \mathrm{mmol})$, HATU $(66.5 \mathrm{mg}, 0.175 \mathrm{mmol})$, and DIPEA (90 $\mu \mathrm{l}$, $69 \mathrm{mg}, 0.525 \mathrm{mmol})$ were dissolved in dry acetonitrile $(2 \mathrm{~mL})$ and stirred for $15 \mathrm{~min}$ at room temperature. Tert-butyl(2-aminoethyl) carbamate $(45 \mu \mathrm{L}, 46 \mathrm{mg}, 0.280 \mathrm{mmol})$ was added to the solution and stirred over night at room temperature. The solvent was evaporated under reduced pressure. The product was purified by column chromatography (dichloromethane/methanol; 20:1, $\left.\mathrm{R}_{\mathrm{f}}=0.22\right)$ and obtained as a colorless oil (118.4 mg, $0.166 \mathrm{mmol}, 94 \%$ ).

${ }^{1} \mathrm{H}-\mathrm{NMR}\left(400 \mathrm{MHz}, \mathrm{CDCl}_{3}\right): \delta[\mathrm{ppm}]=6.34(\mathrm{br}, 1 \mathrm{H}), 5.26(\mathrm{br}, 1 \mathrm{H}), 3.60(\mathrm{~s}, 4 \mathrm{H})$, 3.38-3.34 (m, 2H), 3.26-3.24 (m, 2H), $3.21(\mathrm{~s}, 4 \mathrm{H}), 2.96(\mathrm{~d}, J=14,1 \mathrm{~Hz}, 2 \mathrm{H}), 2.75-2.63(\mathrm{~m}$, 
$2 \mathrm{H}), 2.66-2.63(\mathrm{~m}, 2 \mathrm{H}), 2.59(\mathrm{~d}, J=14,1 \mathrm{~Hz}, 2 \mathrm{H}), 2.19(\mathrm{t}, 2 \mathrm{H}), 1.62-1.53(\mathrm{~m}, 4 \mathrm{H}), 1.43(\mathrm{~s}, 18 \mathrm{H})$, $1.42(\mathrm{~s}, 27 \mathrm{H}), 1.28-1.20(\mathrm{~m}, 2 \mathrm{H})$.

${ }^{13} \mathrm{C}-\mathrm{NMR}\left(400 \mathrm{MHz}, \mathrm{CDCl}_{3}\right): \delta[\mathrm{ppm}]=174.38,173.31,172.80,165.88,82.85,82.77$, $63.44,62.48,62.05,55.48,54.47,47.11,40.81,39.87,35.55,29.82,28.53,28.32,28.14,27.91$, $26,17,23.41$.

MS $\left(\mathrm{ESI}^{+}\right): 714.5[\mathrm{M}+\mathrm{H}]^{+}$, calculated for $\mathrm{C}_{36} \mathrm{H}_{67} \mathrm{~N}_{5} \mathrm{O}_{9}: 713.49[\mathrm{M}]^{+}$.

1,4-Di(acetate)-6-((5-(2-(aminoethyl)amino)-5-oxopentyl)-6-(amino(methyl)-acetate)perhydro-1,4-diazepane (9)

Compound 8 (20 mg, $0.028 \mathrm{mmol}$ ) was dissolved in a solution of dichloromethane and triflouroacetic acid $(2 \mathrm{~mL}, 1: 1)$ and stirred over night at room temperature. The solvent was evaporated under reduced pressure and used without further purification.

MS $\left(\mathrm{ESI}^{+}\right): 446.2[\mathrm{M}+\mathrm{H}]^{+}$, calculated for $\mathrm{C}_{19} \mathrm{H}_{35} \mathrm{~N}_{5} \mathrm{O}_{7}: 445.25[\mathrm{M}]^{+}$.

2-[3-(5-benzyloxycarbonylamino-1-tert-butoxycarbonyl-pentyl)-ureido]-pentanedioic acid di-tert-butyl ester (10)

Triphosgene $(420 \mathrm{mg}, 1.40 \mathrm{mmol})$ was dissolved in dichloromethane $(5 \mathrm{~mL})$ and cooled to $0{ }^{\circ} \mathrm{C}$. A solution of $\mathrm{N}(\varepsilon)$-benzoyloxycarbonyl-L-lysine $(1.42 \mathrm{~g}, 3.80 \mathrm{mmol})$ and triethylamine $(1.05 \mathrm{~mL}, 765 \mathrm{mg}, 7.60 \mathrm{mmol})$ in dichloromethane $(25 \mathrm{~mL})$ was added dropwise over a period of 3 hours at $0{ }^{\circ} \mathrm{C}$. The reaction mixture was stirred for 40 minutes and L-glutamic acid di-tert-butyl ester hydrochloride $(1.13 \mathrm{~g}, 3.80 \mathrm{mmol})$ and triethylamine $(1.05 \mathrm{~mL}, 765 \mathrm{mg}, 7.60 \mathrm{mmol})$ in dichloromethane $(20 \mathrm{~mL})$ was added. The solution was stirred over night at room temperature. The solution was evaporated under reduced pressure. Ethyl acetate $(25 \mathrm{~mL})$ was added. The organic layer was washed with saturated $\mathrm{NaHCO}_{3}$-solution $(2 \times 10 \mathrm{~mL})$ and brine $(2 \times 10 \mathrm{ml})$, dried over sodium sulfate and evaporated under reduced pressure. The residue was purified by column chromatography (hexane/ethyl acetate; 20:1, $\mathrm{R}_{\mathrm{f}}=0.26$ ) and the product was obtained as a colorless oil (357.6 mg, $0.58 \mathrm{mmol}, 41 \%$ ).

${ }^{1} \mathrm{H}-\mathrm{NMR}\left(300 \mathrm{MHz}, \mathrm{CDCl}_{3}\right): \delta[\mathrm{ppm}]=7.38-7.22(\mathrm{~m}, 5 \mathrm{H}), 5.16(\mathrm{~d}, J=13.5 \mathrm{~Hz}, 1 \mathrm{H})$, $5.09(\mathrm{~d}, J=3.2 \mathrm{~Hz}, 2 \mathrm{H}), 4.32(\mathrm{dt}, J=7.5,5.2 \mathrm{~Hz}, 2 \mathrm{H}), 3.16(\mathrm{~s}, 2 \mathrm{H}), 2.40-2.15(\mathrm{~m}, 2 \mathrm{H}), 1.93-1.68$ $(\mathrm{m}, 2 \mathrm{H}), 1.43(\mathrm{~m}, 29 \mathrm{H})$.

${ }^{13} \mathrm{C}-\mathrm{NMR}\left(300 \mathrm{MHz}, \mathrm{CDCl}_{3}\right): \delta[\mathrm{ppm}]=172.54,172.25,172.15,157.09,156.61,136.67$, $128.47,128.04,128.01,82.29,81.84,80.65,77.24,66.56,53.38,53.03,40.63,32.53,31.52,29.36$, $28.28,28.07,28.00,22.26$.

MS $\left(\mathrm{ESI}^{+}\right): 622.4[\mathrm{M}+\mathrm{H}]^{+}, 644.4[\mathrm{M}+\mathrm{Na}]^{+}$, calculated for $\mathrm{C}_{32} \mathrm{H}_{51} \mathrm{~N}_{3} \mathrm{O}_{9}: 621.36[\mathrm{M}]^{+}$.

2-[3-(amino-1-tert-butoxycarbonyl-pentyl)-ureido]-pentanedioic acid di-tert-butyl ester (11)

Compound 10 (337.6 mg, $0.55 \mathrm{mmol})$ was dissolved in methanol ( $3 \mathrm{~mL})$. To this, solution palladium on activated carbon $(22 \mathrm{mg}$ ) was added and the solution was saturated, kept and stirred overnight with hydrogen. Pd/C was filtered over celite and the solvent was evaporated under reduced pressure. The product $(260 \mathrm{mg}, 0.53 \mathrm{mmol}, 96 \%)$ was used without further purification.

${ }^{1} \mathrm{H}-\mathrm{NMR}\left(300 \mathrm{MHz}, \mathrm{CDCl}_{3}\right): \delta[\mathrm{ppm}]=5.48(\mathrm{dd}, J=10.3,8.1 \mathrm{~Hz}, 2 \mathrm{H}), 4.31(\mathrm{dd}, J=5.7$, $2.4 \mathrm{~Hz}, 2 \mathrm{H}), 2.77(\mathrm{t}, J=6.6 \mathrm{~Hz}, 2 \mathrm{H}), 2.36-2.25(\mathrm{~m}, 2 \mathrm{H}), 2.05(\mathrm{ddd}, J=7.1,5.9,2.1 \mathrm{~Hz}, 1 \mathrm{H})$, $1.92-1.68(\mathrm{~m}, 2 \mathrm{H}), 1.44(\mathrm{~d}, J=7.1 \mathrm{~Hz}, 33 \mathrm{H})$.

${ }^{13} \mathrm{C}-\mathrm{NMR}\left(300 \mathrm{MHz}, \mathrm{CDCl}_{3}\right): \delta[\mathrm{ppm}]=172.61,172.47,157.05,82.07,81.67,80.55,53.39$, $52.99,41.12,32.40,31.66,31.43,28.28,28.08,28.02,22.20$.

MS (ESI $\left.{ }^{+}\right): 488.3[\mathrm{M}+\mathrm{H}]^{+}$, calculated for $\mathrm{C}_{24} \mathrm{H}_{45} \mathrm{~N}_{3} \mathrm{O}_{7}: 487.33[\mathrm{M}]^{+}$.

2-[3-(2-(2-ethoxy-3,4-dioxo-cyclobut-1-en-1yl)amino-1-tert-butoxycarbonyl-pentyl)ureido]-pentanedioic acid di-tert-butyl ester (12)

Compound $11(260 \mathrm{mg}, 0.53 \mathrm{mmol})$ was dissolved in $0.5 \mathrm{M}$ phosphate buffer ( $\mathrm{pH} 7$, $2 \mathrm{~mL}), 3,4$-dibutoxycyclobut-3-en-1,2-dione ( $82 \mu \mathrm{L}, 95 \mathrm{mg}, 0.53 \mathrm{mmol}$ ) was added and the $\mathrm{pH}$ was adjusted to 7 . Ethyl acetate $(1 \mathrm{~mL})$ was added and stirred overnight. The solvent was then removed via lyophilization and ethyl acetate $(2 \mathrm{~mL})$ was added. The solution was then filtered and the solvent was removed under reduced pressure. The product ( $248 \mathrm{mg}$, $0.41 \mathrm{mmol}, 77 \%$ ) was obtained as a colorless oil and used without further purification. 
${ }^{1} \mathrm{H}-\mathrm{NMR}\left(300 \mathrm{MHz}, \mathrm{CDCl}_{3}\right): \delta[\mathrm{ppm}]=4.78-4.73(\mathrm{~m}, 2 \mathrm{H}), 4.13(\mathrm{q}, J=7,1 \mathrm{~Hz}, 2 \mathrm{H}), 3.45$ $(\mathrm{d}, J=5,7 \mathrm{~Hz}, 2 \mathrm{H}), 2.36-2.32(\mathrm{~m}, 2 \mathrm{H}), 2.06(\mathrm{~s}, 4 \mathrm{H}), 1.74-1.55(\mathrm{~m}, 2 \mathrm{H}), 1.52-1.43(\mathrm{~m}, 27 \mathrm{H})$, $1.27(\mathrm{t}, J=7,1 \mathrm{~Hz}, 2 \mathrm{H})$.

${ }^{13} \mathrm{C}-\mathrm{NMR}\left(300 \mathrm{MHz}, \mathrm{CDCl}_{3}\right): \delta[\mathrm{ppm}]=189.09,172.22,157.27,124.41,125.10,77.35$, 77.03, 76.71, 70.07, 53.20, 44.39, 31.59, 28.00, 21.93, 21.07, 14.20.

MS $\left(\mathrm{ESI}^{+}\right): 612,4[\mathrm{M}+\mathrm{H}]^{+}$, calculated for $\mathrm{C}_{30} \mathrm{H}_{49} \mathrm{~N}_{3} \mathrm{O}_{10}: 611,34$ [M].

2-[3-(2-(2-ethoxy-3,4-dioxo-cyclobut-1-en-1yl)amino-1-carboxy-pentyl)-ureido]-pentanedioic acid (13)

Compound 12 (50 mg, $0.082 \mathrm{mmol})$ was stirred with a mixture of dichloromethane and trifluoracetic acid ( $2 \mathrm{~mL}, 1: 1)$ at room temperature for 2 hours. The solvent was evaporated under reduced pressure. The product was obtained as a colorless oil $(30.2 \mathrm{mg}, 0.068 \mathrm{mmol}$, $83 \%$ ) and used without further purification.

${ }^{1} \mathrm{H}-\mathrm{NMR}\left(300 \mathrm{MHz}, \mathrm{D}_{2} \mathrm{O}\right): \delta[\mathrm{ppm}]=4.75-4.65(\mathrm{~m}, 2 \mathrm{H}), 4.30-4.12(\mathrm{~m}, 2 \mathrm{H}), 3.59(\mathrm{dt}$, $J=23.5 \mathrm{~Hz}, 6.6 \mathrm{~Hz}, 1 \mathrm{H}), 3.48(\mathrm{t}, J=6.6 \mathrm{~Hz}, 1 \mathrm{H}) 2.49(\mathrm{t}, J=7.3 \mathrm{~Hz}, 2 \mathrm{H}), 2.16(\mathrm{dtd}, J=15.3 \mathrm{~Hz}$, $7.4 \mathrm{~Hz}, 5.2 \mathrm{~Hz}, 1 \mathrm{H}), 2.04-1.90(\mathrm{~m}, 1 \mathrm{H}) 1.86-1.75(\mathrm{~m}, 2 \mathrm{H}), 1.73-1.46(\mathrm{~m}, 3 \mathrm{H}), 1.41(\mathrm{dt}$, $J=7.1 \mathrm{~Hz}, 3.6 \mathrm{~Hz}, 5 \mathrm{H})$.

${ }^{13} \mathrm{C}-\mathrm{NMR}\left(300 \mathrm{MHz}, \mathrm{D}_{2} \mathrm{O}\right): \delta[\mathrm{ppm}]=188.86,182.94,177.13,176.95,176.05,173.15$, $159.08,70.41,52.91,52.48,30.26,29.91,28.86,26.15,21.59,14.95$.

MS $\left(\mathrm{ESI}^{+}\right): 444,2[\mathrm{M}+\mathrm{H}]^{+}$, calculated for $\mathrm{C}_{18} \mathrm{H}_{25} \mathrm{~N}_{3} \mathrm{O}_{10}: 443,15[\mathrm{M}]^{+}$.

DATA $^{5 \mathrm{~m}}$.SA.KuE (14)

Compound 9 (30 mg, $0.067 \mathrm{mmol}$ ) and compound 13 (42 mg, $0.095 \mathrm{mmol}$ ) were dissolved in $0.5 \mathrm{M}$ phosphate buffer $(\mathrm{pH} 9,1 \mathrm{~mL})$. The $\mathrm{pH}$ was adjusted to 9 and stirred for two days at room temperature. The crude product was purified by HPLC (column: LiChrospher $100 \mathrm{RP} 18 \mathrm{EC}(250 \times 10 \mathrm{~mm}) 5 \mu$, flow rate: $5 \mathrm{~mL} / \mathrm{min}, \mathrm{H}_{2} \mathrm{O} / \mathrm{MeCN}+0.1 \% \mathrm{TFA}$, 9 to $15 \% \mathrm{MeCN}$ in $20 \mathrm{~min}$, Rt $=10.1 \mathrm{~min}$ ) to obtain DATA ${ }^{5 \mathrm{~m}} . \mathrm{SA} . \mathrm{KuE}$ as a white powder (5.26 mg, $0.0062 \mathrm{mmol}, 10 \%$ ).

MS $\left(\mathrm{ESI}^{+}\right): 843.3[\mathrm{M}+\mathrm{H}]^{+}, 422.2[\mathrm{M}+2 \mathrm{H}]^{2+}, 441.2[\mathrm{M}+\mathrm{K}+\mathrm{H}]^{2+}$, calculated for $\mathrm{C}_{35} \mathrm{H}_{54} \mathrm{~N}_{8} \mathrm{O}_{16}: 842.37[\mathrm{M}]^{+}$.

\subsection{Radiolabeling}

For radiochemical evaluation, gallium-68 was eluted from a ${ }^{68} \mathrm{Ge} /{ }^{68} \mathrm{Ga}$-generator (ITG Graching, Munich, Germany) and purified manually with ethanol-based post-processing to separate iron, zinc, and germanium impurities [44].

Radiolabeling was performed in $0.4 \mathrm{~mL} 1 \mathrm{M}$ ammonium acetate buffer at $\mathrm{pH} 5.5$. Reactions were carried out with different amounts of precursor (5, 10, 15, $60 \mathrm{nmol})$ and at different temperatures ( $\mathrm{RT}, 50^{\circ} \mathrm{C}$, and $70{ }^{\circ} \mathrm{C}$ ) with $30-50 \mathrm{MBq}$ gallium-68. The $\mathrm{pH}$ was controlled at the start and after the labeling. For reaction control, radio-TLC (TLC Silica gel $60 \mathrm{~F}_{254}$ Merck) and citrate buffer $\mathrm{pH} 4$ as mobile phase and radio-HPLC using an analytical HPLC 7000 series Hitachi LaChrom (Column: Merck Chromolith ${ }^{\circledR}$ RP-18e, linear gradient of $5-95 \% \mathrm{MeCN}(+0.1 \%$ TFA) $/ 95-5 \%$ Water (+0.1\% TFA) in $10 \mathrm{~min})$. TLCs were measured in a TLC imager CR-35 Bio Test-Imager (Elysia-Raytest, Angleur, Belgium) with the analysis software AIDA (Elysia-Raytest, Angleur, Belgium).

Radiolabeling of AAZTA ${ }^{5}$.SA.KuE with scandium- 44 and lutetium-177 was performed according to the literature [17].

\subsection{In Vitro Stability Studies}

Complex stability studies were performed in human serum (HS, human male AB plasma, USA origin, Sigma Aldrich) and phosphate buffered saline (Sigma Aldrich). First, 8-10 MBq of the labeled compound were added to $0.5 \mathrm{~mL}$ of the media. Afterwards, 30, 60, and $120 \mathrm{~min}$ aliquots were taken to evaluate the radiochemical stability. The percentage of complexed gallium-68, which corresponds to the percentage of in vitro radiochemical stability, was determined via radio-TLC. The studies were carried out in triplicate. 


\subsection{In Vitro Binding Affinity}

PSMA binding affinity was determined according to the literature [39]. LNCaP-cells (purchased from Sigma-Aldrich) were cultured in RPMI 1640 (Thermo Fisher Scientific) supplemented with 10\% fetal bovine serum (Thermo Fisher Scientific), $100 \mu \mathrm{g} / \mathrm{ml}$ streptomycin, and 100 units $/ \mathrm{mL}$ penicillin at $37^{\circ} \mathrm{C}$ in $5 \% \mathrm{CO}_{2}$ in a humidified atmosphere. The medium was changed approximately every 3 days. Cells in exponential phase of growth were harvested by a 5 min treatment with a $0.05 \%$ trypsin- $-0.02 \%$ EDTA solution and neutralized with serum-containing medium prior to counting.

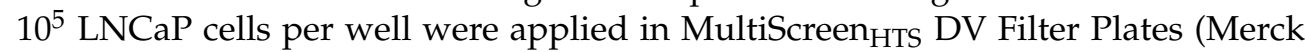
Millipore) and incubated with $0.75 \mathrm{nM}\left[{ }^{68} \mathrm{Ga}\right] \mathrm{Ga}$-PSMA-10 in the presence of 12 increasing concentrations of the non-labeled SA-conjugated compounds. After incubation at room temperature for $45 \mathrm{~min}$, cells bound on the filter plates were washed several times with ice-cold PBS to remove free radioactivity. The cell-bound activity was determined by punching out the filters and transferring them into individual tubes for measurement in a $\gamma$-counter (2480 WIZARD 2 Automatic Gamma Counter, PerkinElmer, Waltham, MA, USA). Data were analyzed in GraphPad Prism 9 using nonlinear regression. Experiments were replicated 4-times.

\subsection{Internalization Ratio}

Internalization ratio was determined according to the literature [45,46]. Prior to seeding cells, 24 -well plates were coated with $0.1 \%$ poly-L-lysine (Sigma-Aldrich) in PBS for $20 \mathrm{~min}$ at room temperature. Subsequently, $10^{5} \mathrm{LNCaP}$ cells in $1 \mathrm{~mL}$ RPMI 1640 Medium were added in each well and incubated for $24 \mathrm{~h}$ at $37^{\circ} \mathrm{C}$. Then, $250 \mu \mathrm{L}$ of the ${ }^{68} \mathrm{Ga}$-labeled compounds in Opti-MEM ${ }^{\mathrm{TM}}$ I Reduced Serum (ThermoFisher) were added to each well to a final concentration of $30 \mathrm{nM}$. The plates were then incubated for $45 \mathrm{~min}$ at $4{ }^{\circ} \mathrm{C}$ and $37^{\circ} \mathrm{C}$ respectively either with or without adding PMPA (Sigma-Aldrich) to a final concentration of $500 \mu \mathrm{M}$. The supernatant was removed and the cells were washed several times with ice-cold PBS. Afterwards, cells were incubated twice with $50 \mathrm{mM}$ glycine buffer $\mathrm{pH} 2.8$ for $5 \mathrm{~min}$ to remove the surface-bound radioactivity. In order to determine the internalized fraction of the compounds, cells were lysed by incubation with $0.3 \mathrm{M} \mathrm{NaOH}$ for $10 \mathrm{~min}$.

\subsection{Animal Studies}

Six- to eight-week-old male BALB/cAnNRj (Janvier Labs) were inoculated subcutaneously with $5 \times 10^{6}$ LNCaP cells in $200 \mu \mathrm{L}$ 1:1 (v/v) Matrigel/PBS (Corning $\left.{ }^{\circledR}\right)$. In vivo and $e x$ vivo experiments are conducted after tumors reached a volume of approximately $100 \mathrm{~mm}^{3}$.

LNCaP-xenografts were anesthetized with $2 \%$ isoflurane prior to i.v. injection of $0.5 \mathrm{nmol}$ of the radiolabeled compounds. The specific activities of the tracers were approximately $10 \mathrm{MBq} / \mathrm{nmol}, 6 \mathrm{MBq} / \mathrm{nmol}$, and $15 \mathrm{MBq} / \mathrm{nmol}$ of gallium-68-labeled compounds, ${ }^{[4}{ }^{44}$ Sc]Sc-AAZTA ${ }^{5}$.SA.KuE and $\left[{ }^{177} \mathrm{Lu}\right]$ Lu-AAZTA ${ }^{5}$.SA.KuE, respectively. For blocking experiments, mice were co-injected with $1.5 \mu \mathrm{mol}$ PMPA/mouse.

Biodistribution studies. The number of animals used in this study was: $\left[{ }^{68} \mathrm{Ga}\right] \mathrm{Ga}-$ DATA $^{5 \mathrm{~m}} \cdot$ SA.KuE $\mathrm{n}=5 ;\left[{ }^{44} \mathrm{Sc}\right] \mathrm{Sc}-\mathrm{AAZTA}{ }^{5} . \mathrm{SA} \cdot \mathrm{KuE} \mathrm{n}=2 ;\left[{ }^{177} \mathrm{Lu}\right] \mathrm{Lu}-\mathrm{AAZTA}{ }^{5} \cdot \mathrm{SA} \cdot \mathrm{KuE} \mathrm{n}=2$; $\left[{ }^{68} \mathrm{Ga}\right] \mathrm{Ga}-\mathrm{PSMA}-11 \mathrm{n}=2 ;\left[{ }^{44} \mathrm{Sc}\right] \mathrm{Sc}-\mathrm{AAZTA}{ }^{5} . \mathrm{SA} \cdot \mathrm{KuE}+\mathrm{PMPA} \mathrm{n}=1$. Animals were sacrificed $1 \mathrm{~h}$ p.i. Organs of interest were collected and weighed. The radioactivity was measured and calculated as a decay-corrected percentage of the injected dose per gram of tissue mass $\% \mathrm{ID} / \mathrm{g}$.

MicroPET-imaging. After i.v. injection of the labeled compounds, anesthetized mice (one mouse for each group) were placed in the prone position in a nanoScan ${ }^{\circledR} \mathrm{PET} / \mathrm{MR}$ (Mediso). MRI measurements were performed followed by a static PET scan with the nanoScan PET/MRI (Mediso, Budapest, Hungary). PET data were reconstructed with Teratomo 3D (four iterations, six subsets, voxel size $0.4 \mathrm{~mm}$ ), co-registered to the MR, and analyzed with Pmod software (version 3.6) (PMOD Technologies LLC, Zürich, Switzerland) Material Map for co-registration of the PET scan; 3D Gradient Echo External Averaging 
(GRE-EXT), Multi Field of View (FOV); slice thickness, 0.6 mm; TE, 2 ms; TR, 15 ms; flip angle, 25 deg.

\section{Conclusions}

In summary, the synthesized hybrid chelator-based PSMAradiopharmaceuticals DATA $^{5 \mathrm{~m}}$.SA.KuE and AAZTA ${ }^{5}$.SA.KuE could be labeled at mild conditions with high radiochemical yields. The stability of the labeled compounds in PBS and human serum was demonstrated. Both SA.KuE conjugates displayed good PSMA binding affinities in LNCaP cells along with good internalization ratios. Additionally, $\left[{ }^{68} \mathrm{Ga}\right] \mathrm{Ga}-\mathrm{DATA}{ }^{5 \mathrm{~m}}$.SA.KuE, $\left[{ }^{44} \mathrm{Sc}\right] \mathrm{Sc}-\mathrm{AAZTA}{ }^{5}$.SA.KuE, and $\left[{ }^{177} \mathrm{Lu}\right] \mathrm{Lu}-\mathrm{AAZTA}{ }^{5}$.SA.KuE showed similar in vivo behavior, suggesting that the exchange of either the chelator or the nuclide does not impact the pharmacokinetic of the investigated compounds. This finding renders $\left[{ }^{44} \mathrm{Sc}\right] \mathrm{Sc}-$ AAZTA ${ }^{5}$.SA.KuE and $\left[{ }^{177} \mathrm{Lu}\right] \mathrm{Lu}-\mathrm{AAZTA}{ }^{5}$.SA.KuE an interesting pair for theranostic application. Tumor accumulation of the tested PSMA radioligands was similar to that of $\left[{ }^{68} \mathrm{Ga}\right] \mathrm{Ga}-\mathrm{PSMA}-11$, although lower than the value reported in literature for PSMA-617. The decreased kidney uptake of the SA.KuE conjugates is noteworthy, which could be a major benefit in reducing irradiation of the kidneys, resulting in lower nephrotoxicity and improved tolerability.

Author Contributions: Conceptualization, F.R., H.L., T.G. and L.G.; methodology, H.L., T.G., L.G. and S.P.; software, H.L., T.G. and S.P.; validation, H.L. and T.G., formal analysis, H.L. and T.G.; investigation, H.L. and T.G.; data curation, H.L. and T.G.; writing-original draft preparation, H.L. and T.G.; writing-review and editing, H.L., T.G., L.G., S.P., M.S. and F.R.; supervision, F.R. and M.S. All authors have read and agreed to the published version of the manuscript.

Funding: This research received no external funding.

Institutional Review Board Statement: The study was conducted according to the guidelines of the Declaration of Helsinki, and approved by the Ethics Committee of the state of Rhineland Palatinate according to §8 Abs. 1 Tierschutzgesetz, Landesuntersuchungsamt (23 177-07 G 15-1-033).

Informed Consent Statement: Not applicable.

Data Availability Statement: The data presented in this study are available on request from the corresponding author.

Acknowledgments: The authors thank the Max Planck Graduate Center Mainz (MPGC) for supporting Tilmann Grus and Lukas Greifenstein. The authors gratefully acknowledge Avicenna-Studienwerk and Mainz Research School of Translational Biomedicine (TransMed) for supporting Hanane Lahnif. The authors thank ITG Munich for supplying lutetium-177 and gallium-68-generators.

Conflicts of Interest: The authors declare no conflict of interest.

Sample Availability: Not available.

\section{References}

1. Chang, S.S.; Heston, W.D.W. The clinical role of prostate-specific membrane antigen (PSMA). Urol. Oncol. 2002, 7, 7-12. [CrossRef]

2. Chang, S.S.; Bander, N.H.; Heston, W.D.W. Biology of PSMA as a Diagnostic and Therapeutic Target. In Management of Prostate Cancer; Klein, E.A., Ed.; Humana Press: Totowa, NJ, USA, 2004; pp. 609-630.

3. Gourni, E.; Henriksen, G.; Gamez, P.; Caballero, A.B. Metal-based PSMA radioligands. Molecules 2017, 22, 523. [CrossRef]

4. Silver, D.A.; Pellicer, I.; Fair, W.R.; Heston, W.D.; Cordon-Cardo, C. Prostate-specific membrane antigen expression in normal and malignant human tissues. Clin. Cancer Res. 1997, 3, 81-85. [PubMed]

5. Perner, S.; Hofer, M.D.; Kim, R.; Shah, R.B.; Li, H.; Möller, P.; Hautmann, R.E.; Gschwend, J.E.; Kuefer, R.; Rubin, M.A. Prostatespecific membrane antigen expression as a predictor of prostate cancer progression. Hum. Pathol. 2007, 38, 696-701. [CrossRef] [PubMed]

6. Prostate Cancer Statistics I World Cancer Research Fund International. Available online: https://www.wcrf.org/dietandcancer/ prostate-cancer-statistics / (accessed on 19 May 2021).

7. Ferlay, J.; Colombet, M.; Soerjomataram, I.; Mathers, C.; Parkin, D.M.; Piñeros, M.; Znaor, A.; Bray, F. Estimating the global cancer incidence and mortality in 2018: GLOBOCAN sources and methods. Int. J. Cancer 2019, 144, 1941-1953. [CrossRef] [PubMed]

8. Rawla, P. Epidemiology of Prostate Cancer. World J. Oncol. 2019, 10, 63-89. [CrossRef] [PubMed] 
9. Kirby, M.; Hirst, C.; Crawford, E.D. Characterising the castration-resistant prostate cancer population: A systematic review. Int. J. Clin. Pract. 2011, 65, 1180-1192. [CrossRef]

10. Kopka, K.; Benešová, M.; Bařinka, C.; Haberkorn, U.; Babich, J. Glu-ureido-based inhibitors of prostate-specific membrane antigen: Lessons learned during the development of a novel class of low-molecular-weight theranostic radiotracers. J. Nucl. Med. 2017, 58, 17S-26S. [CrossRef]

11. Benesová, M.; Schäfer, M.; Bauder-Wüst, U.; Afshar-Oromieh, A.; Kratochwil, C.; Mier, W.; Haberkorn, U.; Kopka, K.; Eder, M. Preclinical evaluation of a tailor-made DOTA-conjugated PSMA inhibitor with optimized linker moiety for imaging and endoradiotherapy of prostate cancer. J. Nucl. Med. 2015, 56, 914-920. [CrossRef]

12. Valstar, M.H.; de Bakker, B.S.; Steenbakkers, R.J.H.M.; de Jong, K.H.; Smit, L.A.; Klein Nulent, T.J.W.; van Es, R.J.J.; Hofland, I.; de Keizer, B.; Jasperse, B.; et al. The tubarial salivary glands: A potential new organ at risk for radiotherapy. Radiother. Oncol. 2021, 154, 292-298. [CrossRef]

13. Rupp, N.J.; Umbricht, C.A.; Pizzuto, D.A.; Lenggenhager, D.; Töpfer, A.; Müller, J.; Muehlematter, U.J.; Ferraro, D.A.; Messerli, M.; Morand, G.B.; et al. First clinicopathologic evidence of a non-PSMA-related uptake mechanism for 68Ga-PSMA-11 in salivary glands. J. Nucl. Med. 2019, 60, 1270-1276. [CrossRef] [PubMed]

14. Afshar-Oromieh, A.; Malcher, A.; Eder, M.; Eisenhut, M.; Linhart, H.G.; Hadaschik, B.A.; Holland-Letz, T.; Giesel, F.L.; Kratochwil, C.; Haufe, S.; et al. Pet imaging with a [68ga]gallium-labelled psma ligand for the diagnosis of prostate cancer: Biodistribution in humans and first evaluation of tumour lesions. Eur. J. Nucl. Med. Mol. Imaging 2013, 40, 486-495. [CrossRef] [PubMed]

15. Hofman, M.S.; Hicks, R.J.; Maurer, T.; Eiber, M. Prostate-specific membrane antigen PET: Clinical utility in prostate cancer, normal patterns, pearls, and pitfalls. Radiographics 2018, 38, 200-217. [CrossRef]

16. Farkas, E.; Nagel, J.; Waldron, B.P.; Parker, D.; Tóth, I.; Brücher, E.; Rösch, F.; Baranyai, Z. Equilibrium, Kinetic and Structural Properties of Gallium(III) and Some Divalent Metal Complexes Formed with the New DATAm and DATA5m Ligands. Chem. Eur. J. 2017, 23, 10358-10371. [CrossRef]

17. Greifenstein, L.; Grus, T.; Nagel, J.; Sinnes, J.P.; Rösch, F. Synthesis and labeling of a squaric acid containing PSMA-inhibitor coupled to AAZTA5 for versatile labeling with 44Sc, 64Cu, 68Ga and 177Lu. Appl. Radiat. Isot. 2020, 156, 108867. [CrossRef] [PubMed]

18. Baranyai, Z.; Uggeri, F.; Giovenzana, G.B.; Bényei, A.; Brücher, E.; Aime, S. Equilibrium and kinetic properties of the lanthanoids(III) and various divalent metal complexes of the heptadentate ligand AAZTA. Chem. Eur. J. 2009, 15, 1696-1705. [CrossRef] [PubMed]

19. Seemann, J.; Waldron, B.P.; Roesch, F.; Parker, D. Approaching “kit-type” labelling with 68Ga: The DATA chelators. Chem. Med. Chem. 2015, 10, 1019-1026. [CrossRef] [PubMed]

20. Waldron, B.P.; Parker, D.; Burchardt, C.; Yufit, D.S.; Zimny, M.; Roesch, F. Structure and stability of hexadentate complexes of ligands based on AAZTA for efficient PET labelling with gallium-68. Chem. Comm. 2013, 49, 579-581. [CrossRef]

21. Nagy, G.; Szikra, D.D.; Trencsényi, G.; Fekete, A.; Garai, I.; Giani, A.M.; Negri, R.; Masciocchi, N.; Maiocchi, A.; Uggeri, F.; et al. AAZTA: An Ideal Chelating Agent for the Development of44Sc PET Imaging Agents. Angew. Chem. Int. Ed. Engl. 2017, 56, 2118-2122. [CrossRef]

22. Aime, S.; Calabi, L.; Cavallotti, C.; Gianolio, E.; Giovenzana, G.B.; Losi, P.; Maiocchi, A.; Palmisano, G.; Sisti, M.; Giuria, V.P.; et al. [Gd-AAZTA]-: A new structural entry for an improved generation of MRI contrast agents. Inorg. Chem. 2004, 43, 7588-7590. [CrossRef]

23. Tsionou, M.I.; Knapp, C.E.; Foley, C.A.; Munteanu, C.R.; Cakebread, A.; Imberti, C.; Eykyn, T.R.; Young, J.D.; Paterson, B.M.; Blower, P.J.; et al. Comparison of macrocyclic and acyclic chelators for gallium-68 radiolabelling. RSC Adv. 2017, 7, 49586-49599. [CrossRef]

24. Benešová, M.; Bauder-Wüst, U.; Schäfer, M.; Klika, K.D.; Mier, W.; Haberkorn, U.; Kopka, K.; Eder, M. Linker Modification Strategies to Control the Prostate-Specific Membrane Antigen (PSMA)-Targeting and Pharmacokinetic Properties of DOTAConjugated PSMA Inhibitors. J. Med. Chem. 2016, 59, 1761-1775. [CrossRef]

25. Zhang, A.X.; Murelli, R.P.; Barinka, C.; Michel, J.; Cocleaza, A.; Jorgensen, W.L.; Lubkowski, J.; Spiegel, D.A. A Remote arenebinding site on prostate specific membrane antigen revealed by antibody-recruiting small molecules. J. Am. Chem Soc. 2010, 132, 12711-12716. [CrossRef]

26. Tietze, L.F.; Arlt, M.; Beller, M.; Gliisenkampb, K.; Jahdeb, E.; Rajewskyb, M.F.; Gl üsenkamp, K.-H.; Jähde, E.; Rajewsky, M.F. Anticancer Agents, 15. Squaric Acid Diethyl Ester: A New Coupling Reagent for the Formation of Drug Biopolymer Conjugates. Synthesis of Squaric Acid Ester Amides and Diamides. Chem Ber. 1991, 124, 1215-1221. [CrossRef]

27. Wurm, F.R.; Klok, H.A. Be squared: Expanding the horizon of squaric acid-mediated conjugations. Chem Soc. Rev. 2013, 42, 8220-8236. [CrossRef]

28. Greifenstein, L.; Engelbogen, N.; Lahnif, H.; Sinnes, J.P.J.-P.; Bergmann, R.; Bachmann, M.; Rösch, F. Synthesis, Labeling and Preclinical Evaluation of a Squaric Acid Containing PSMA Inhibitor Labeled with 68Ga: A Comparison with PSMA-11 and PSMA-617. Chem. Med. Chem 2020, 15, 695-704. [CrossRef]

29. Grus, T.; Lahnif, H.; Klasen, B.; Moon, E.-S.; Greifenstein, L.; Roesch, F. Squaric Acid-Based Radiopharmaceuticals for Tumor Imaging and Therapy. Bioconj. Chem. 2021, 32, 1223-1231. [CrossRef]

30. Prohens, R.; Portell, A.; Font-Bardia, M.; Bauzá, A.; Frontera, A. Experimental and theoretical study of aromaticity effects in the solid state architecture on squaric acid derivatives. Cryst. Growth Des. 2014, 14, 2578-2587. [CrossRef]

31. Quiñonero, D.; Frontera, A.; Ballester, P.; Deyà, P.M. A theoretical study of aromaticity in squaramide and oxocarbons. Tetrahedron Lett. 2000, 41, 2001-2005. [CrossRef] 
32. Dingels, C.; Wurm, F.; Wagner, M.; Klok, H.A.; Frey, H. Squaric acid mediated chemoselective PEGylation of proteins: Reactivity of single-step-activated $\alpha$-amino poly(ethylene glycol)s. Chem. Eur. J. 2012, 18, 16828-16835. [CrossRef] [PubMed]

33. Liu, H.; Rajasekaran, A.K.; Moy, P.; Xia, Y.; Kim, S.; Navarro, V.; Rahmati, R.; Bander, N.H. Constitutive and Antibody-induced Internalization of Prostate-specific Membrane Antigen. Cancer Res. 1998, 58, 4055-4060.

34. Winter, G.; Vogt, A.; Jiménez-Franco, L.D.; Rinscheid, A.; Yousefzadeh-Nowshahr, E.; Solbach, C.; Beer, A.J.; Glatting, G.; Kletting, P. Modelling the internalisation process of prostate cancer cells for PSMA-specific ligands. Nucl. Med. Biol. 2019, 72-73, 20-25. [CrossRef] [PubMed]

35. Jackson, P.F.; Tays, K.L.; Maclin, K.M.; Ko, Y.S.; Li, W.; Vitharana, D.; Tsukamoto, T.; Stoermer, D.; Lu, X.C.; Wozniak, K.; et al. Design and Pharmacological Activity of Phosphinic Acid Based NAALADase Inhibitors. J. Med. Chem. 2001, 44, 4170-4175. [CrossRef] [PubMed]

36. Jackson, P.F.; Cole, D.C.; Slusher, B.S.; Stetz, S.L.; Ross, L.E.; Donzanti, B.A.; Trainor, D.A. Design, Synthesis, and Biological Activity of a Potent Inhibitor of the Neuropeptidase N-Acetylated $\alpha$-Linked Acidic Dipeptidase. J. Med. Chem. 1996, 39, 619-622. [CrossRef] [PubMed]

37. Rais, R.; Rojas, C.; Wozniak, K.; Wu, Y.; Zhao, M.; Tsukamoto, T.; Rudek, M.A.; Slusher, B.S. Bioanalytical method for evaluating the pharmacokinetics of the GCP-II inhibitor 2-phosphonomethyl pentanedioic acid (2-PMPA). J. Pharm Biomed. Anal. 2014, 88, 162-169. [CrossRef]

38. Killock, D. PSMA PET-CT improves staging. Nat. Rev. Clin. Oncol. 2020, 17, 337. [CrossRef]

39. Langbein, T.; Chaussé, G.; Baum, R.P. Salivary gland toxicity of PSMA radioligand therapy: Relevance and preventive strategies. J. Nucl. Med. 2018, 59, 1172-1173. [CrossRef]

40. Sinnes, J.-P.; Bauder-Wüst, U.; Schäfer, M.; Moon, E.S.; Kopka, K.; Rösch, F. 68Ga, 44Sc and 177Lu-labeled AAZTA5-PSMA-617: Synthesis, radiolabeling, stability and cell binding compared to DOTA-PSMA-617 analogues. EJNMMI Radiopharm. Chem. 2020, 5, 28. [CrossRef]

41. Ghiani, S.; Hawala, I.; Szikra, D.; Trencsényi, G.; Baranyai, Z.; Nagy, G.; Vágner, A.; Stefania, R.; Pandey, S.; Maiocchi, A. Synthesis, radiolabeling, and pre-clinical evaluation of [ $44 \mathrm{Sc}$ ]Sc-AAZTA conjugate PSMA inhibitor, a new tracer for high-efficiency imaging of prostate cancer. Eur. J. Nucl. Med. Mol. Imaging 2021, 48, 2351-2362. [CrossRef]

42. Eppard, E.; de la Fuente, A.; Benešová, M.; Khawar, A.; Bundschuh, R.A.; Gärtner, F.C.; Kreppel, B.; Kopka, K.; Essler, M.; Rösch, F. Clinical translation and first in-human use of [44Sc]Sc-PSMA-617 for pet imaging of metastasized castrate-resistant prostate cancer. Theranostics 2017, 7, 4359-4369. [CrossRef]

43. Schäfer, M.; Bauder-Wust, U.; Leotta, K. A dimerized urea-based inhibitor of the prostate-specific membrane antigen for 68Ga-PET imaging of prostate cancer. EJNMMI Res. 2012, 2, 23. [CrossRef] [PubMed]

44. Eppard, E.; Wuttke, M.; Nicodemus, P.L.; Rösch, F. Ethanol-based post-processing of generator-derived 68Ga Toward kit-type preparation of 68Ga-radiopharmaceuticals. J. Nucl. Med. 2014, 55, 1023-1028. [CrossRef] [PubMed]

45. Eder, M.; Schäfer, M.; Bauder-Wüst, U.; Hull, W.E.; Wängler, C.; Mier, W.; Haberkorn, U.; Eisenhut, M. 68Ga-complex lipophilicity and the targeting property of a urea-based PSMA inhibitor for PET imaging. Bioconj. Chem. 2012, 23, 688-697. [CrossRef]

46. Askoxylakis, V.; Mier, W.; Zitzmann, S.; Ehemann, V.; Zhang, J.; Krämer, S.; Beck, C.; Schwab, M.; Eisenhut, M.; Haberkorn, U. Characterization and development of a peptide (p160) with affinity for neuroblastoma cells. J. Nucl. Med. 2006, 47, 981-988. [PubMed] 